\title{
Green Nanotechnology: Plant-Mediated Nanoparticle Synthesis and Application
}

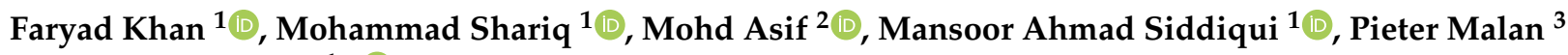 \\ and Faheem Ahmad $1, *$ (i)
}

Citation: Khan, F.; Shariq, M.; Asif, M.; Siddiqui, M.A.; Malan, P.; Ahmad, F. Green Nanotechnology: Plant-Mediated Nanoparticle Synthesis and Application. Nanomaterials 2022, 12, 673. https:// doi.org/10.3390/nano12040673

Academic Editor: Emilia Iglesias Martínez

Received: 9 January 2022

Accepted: 3 February 2022

Published: 17 February 2022

Publisher's Note: MDPI stays neutral with regard to jurisdictional claims in published maps and institutional affiliations.

Copyright: (C) 2022 by the authors. Licensee MDPI, Basel, Switzerland. This article is an open access article distributed under the terms and conditions of the Creative Commons Attribution (CC BY) license (https:// creativecommons.org/licenses/by/ $4.0 /)$.
1 Department of Botany, Aligarh Muslim University, Aligarh 202002, India; khanfaryadamu@gmail.com (F.K.); ansarishariq.amu@gmail.com (M.S.); mansoor_bot@yahoo.co.in (M.A.S.)

2 Regional Ayurveda Research Institute, CCRAS, Ranikhet 263645, India; asifgc2616@gmail.com

3 Unit for Environmental Sciences and Management, Mafikeng Campus, North-West University, Mmabatho 2735, South Africa; pieter.malan@nwu.ac.za

* Correspondence: faheem.bt@amu.ac.in

\begin{abstract}
The key pathways for synthesizing nanoparticles are physical and chemical, usually expensive and possibly hazardous to the environment. In the recent past, the evaluation of green chemistry or biological techniques for synthesizing metal nanoparticles from plant extracts has drawn the attention of many researchers. The literature on the green production of nanoparticles using various metals (i.e., gold, silver, zinc, titanium and palladium) and plant extracts is discussed in this study. The generalized mechanism of nanoparticle synthesis involves reduction, stabilization, nucleation, aggregation and capping, followed by characterization. During biosynthesis, major difficulties often faced in maintaining the structure, size and yield of particles can be solved by monitoring the development parameters such as temperature, $\mathrm{pH}$ and reaction period. To establish a widely accepted approach, researchers must first explore the actual process underlying the plantassisted synthesis of a metal nanoparticle and its action on others. The green synthesis of NPs is gaining attention owing to its facilitation of the development of alternative, sustainable, safer, less toxic and environment-friendly approaches. Thus, green nanotechnology using plant extract opens up new possibilities for the synthesis of novel nanoparticles with the desirable characteristics required for developing biosensors, biomedicine, cosmetics and nano-biotechnology, and in electrochemical, catalytic, antibacterial, electronics, sensing and other applications.
\end{abstract}

Keywords: biosynthesis; eco-friendly; green chemistry; nanoparticle; plant extract; sustainable application

\section{Introduction}

The nanotechnology sector has proven to be one of the most active research fields [1]. Owing to their broad uses in catalysis, sensing, electronics, photonics and medicines, the synthesis of nanoparticles has gained significant attention in recent decades [2]. Scientists have understood the potential of biological organisms to reduce metal precursors since the nineteenth century, but the mechanisms are still not known. Researchers have drawn attention towards biological methods due to the success of nanoparticle synthesis using natural reduction, capping and stabilizing agents, and avoiding harmful chemicals and high energy consumption [3-5]. A wide variety of products (e.g., Quantum dots (Q-dots) of cadmium sulphide, titanium oxide hybrid-based electrochemical biosensors and oxorubicin-loaded heparinized nanoparticles) can be developed through nanotechnology, and applicable to a broad array of scientific fields, including optoelectronics, biosensors, nano-biotechnology, biomedicine and others [6-9]. Creation, exploitation and synthesis are nanotechnology concepts that typically consider materials smaller than $1 \mathrm{~mm}$ in dimension [10]. Many different methods, such as physical, chemical and green (biological) techniques, have been used to synthesize nanoparticles [11-13]. The stabilized nanoparticles are formed by reducing 
ions through reduction (palladium NPs), nucleation (silver NPs) and growth system (silver NPs) [14-16]. Green chemistry, which uses chemical principles to reduce or eliminate the use of hazardous substances, has led to considerable reductions in toxic residues, which are harmful to man and the environment.

Green chemistry may be defined as chemical-assisted pollution-prevention strategies employed in specific domains such as green analytical chemistry, ecologically friendly analytical chemistry and clean analytical methodologies [17]. Thus, green synthesis is regarded as a viable approach for nanoparticle synthesis since it is biocompatible, inert and environmentally safe [18].

\section{Different Types of Nanotechnologies}

In general, the three types of nanotechnologies are wet, dry and computational. Wet nanotechnology is concerned with the investigation of living organisms and their components such as tissues [19], enzymes and membranes [20] that are predominantly found in water-based systems [21]. Physical chemistry and inorganic compounds such as carbon and silicon are associated with dry nanotechnology. On the other hand, computational nanotechnology is associated with simulations of nanometer-sized components [22]. The three nanotechnologies, viz., wet, dry and computational, are interdependent for optimal functionality (Figure 1).

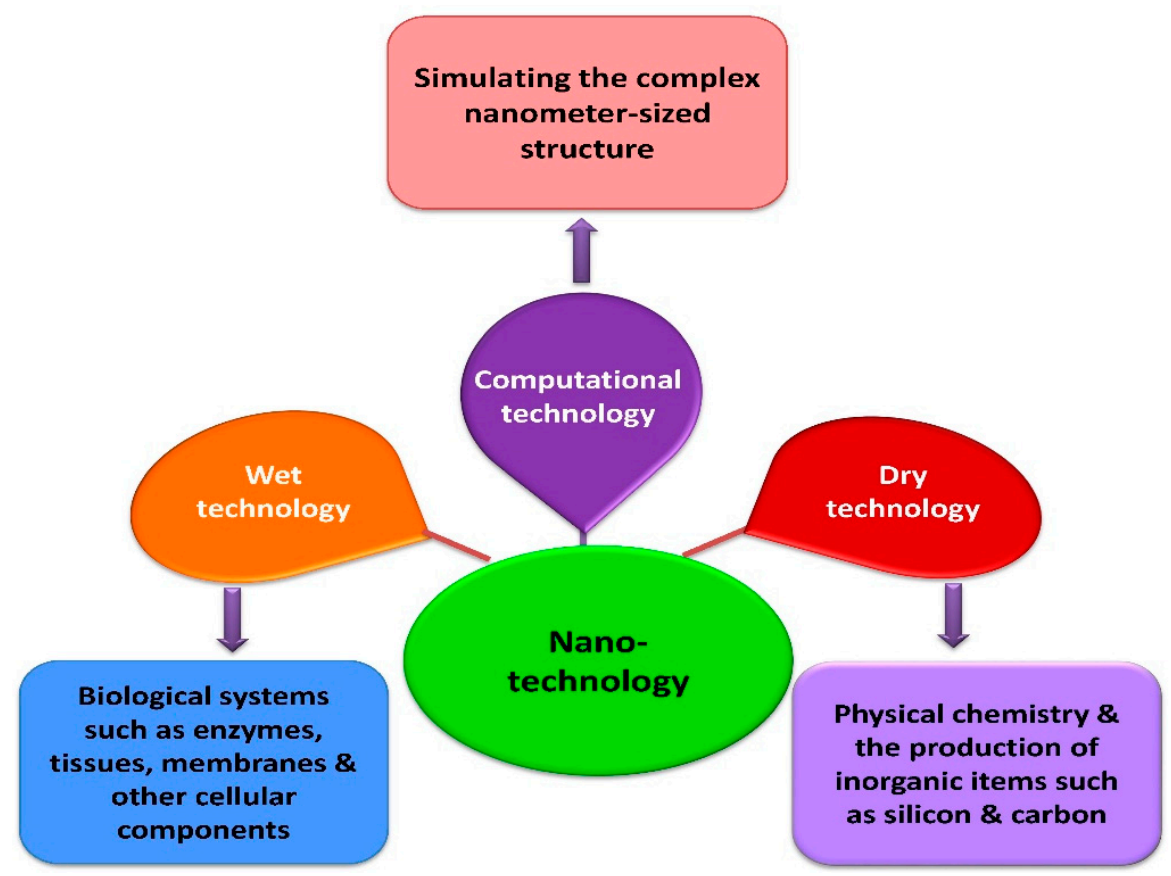

Figure 1. Different types of nanotechnologies.

\section{Biosynthesis of Novel Metal Nanoparticles Using Plant Extracts}

Nanoparticles with sizes ranging from 1 to $100 \mathrm{~nm}$ bind larger particles to atomic or molecular structures [23]. They are synthesized via different approaches, mainly divided into physical and chemical processes (Figure 2). The physical process involves laser ablation, condensation, evaporation, etc., whereas the chemical process involves hydrazine, sodium borohydride, green synthesis, etc. Using plant species to produce nanoparticles has been termed a green technique (Figures 2 and 3) and the most reliable environmentally sustainable approach [24,25]. Nowadays, researchers are attracted towards biological synthesis, including the use of natural reducing, capping and stabilizing agents and without using hazardous, high-cost chemicals and high power consumption [26] (Figures 2 and 3). NPs are extensively utilized in human contact areas (medicine, [27,28] and agriculture, [29,30]), and synthesis methods that do not use harmful compounds are increasingly required. 


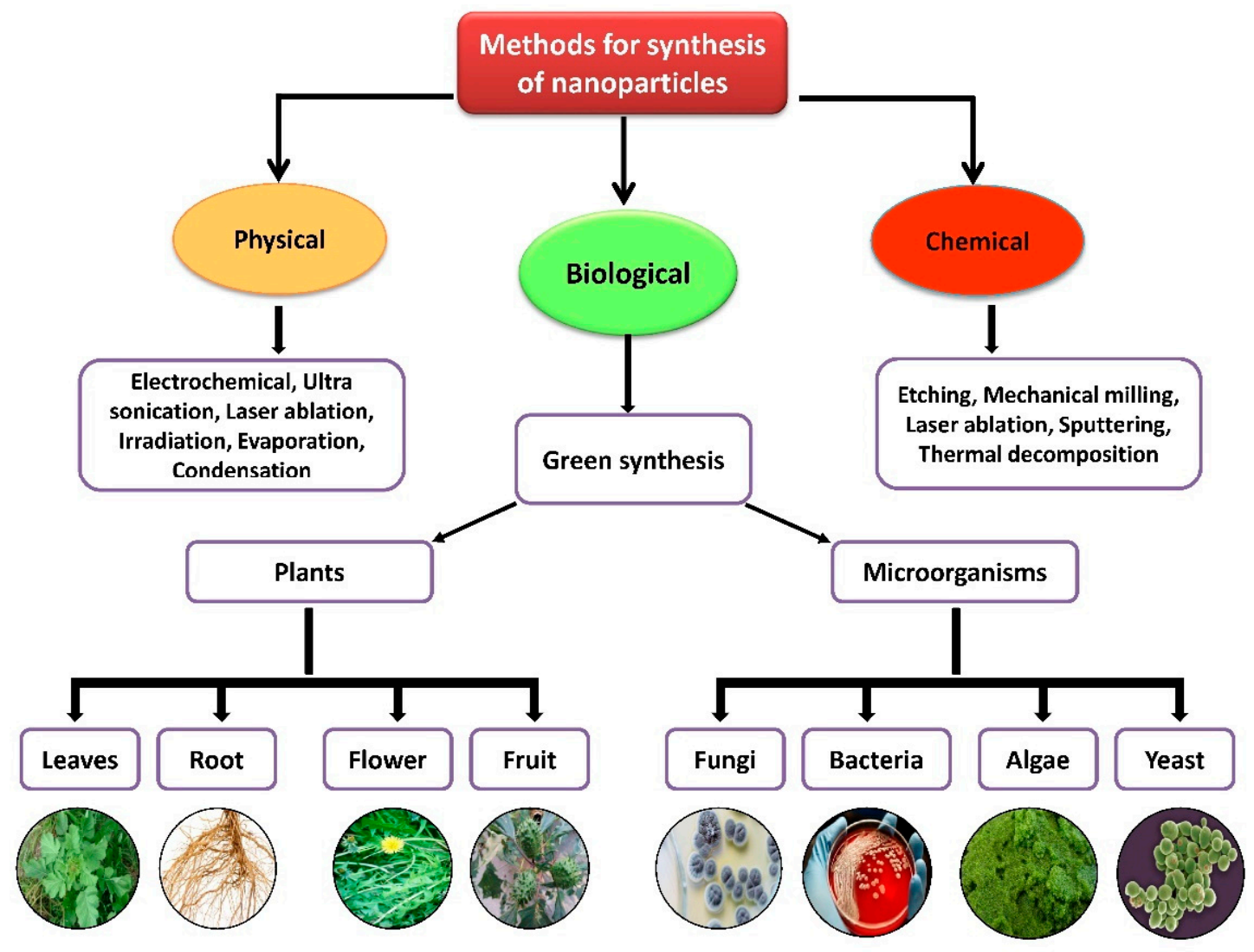

Figure 2. Different methods of nanoparticle synthesis.

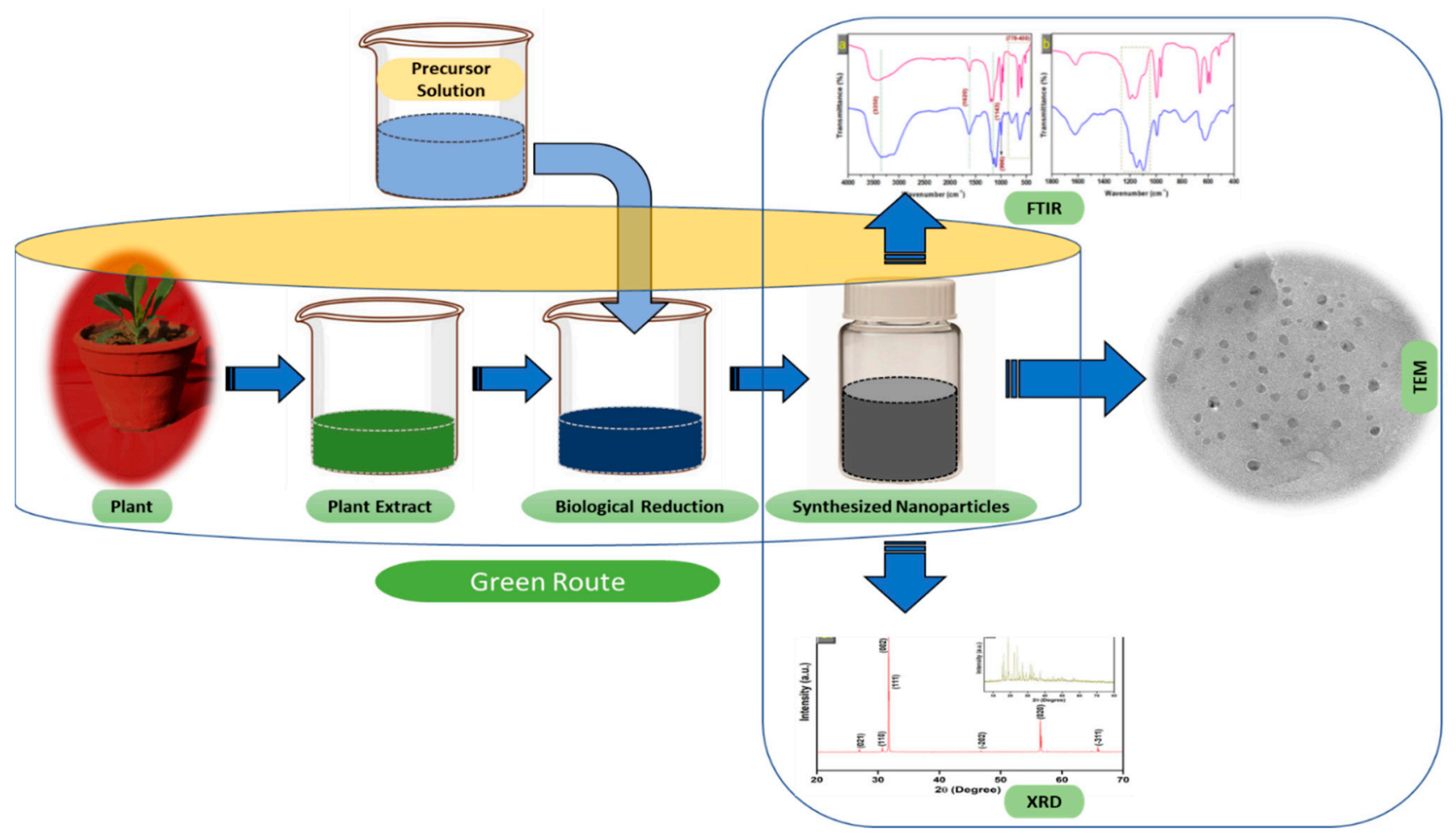

Figure 3. The schematic diagram for the biosynthesis of nanoparticles (NPs) via a green route using plant extract. 


\subsection{Mechanism of Nanoparticle Synthesis}

Extensive research has been published on the testing and assessing of plants to prepare metallic nanoparticles (Figure 3), but the underlying principle for synthesizing nanomaterials has received comparatively less scientific attention [31,32]. The general tools, steps and materials involved in nanoparticle synthesis include reducing agents, capping agents, solvents, metal salts, nucleation, growth, aggregation, stabilization and characterization (Figure 4). Chemical reduction is commonly used in nanoparticle synthesis. Most methods utilize highly reactive reducing agents such as amino acids, citric acid, aldehydes, flavonoids, NADP reductase, tartaric acids, secondary metabolites, etc. Two researchers reported that the reduction potential of each metal is different and greatly affect the reduction of metals or metal precursors during synthesis. If the positive reduction potential is more, the metal precursor can be reduced at a faster rate. The nucleation and growth phases will be close to equilibrium when the reducing rate is slow [33,34]. In one-step synthesis, the slow reduction rate is also a key factor in the production of $\mathrm{Au}-\mathrm{Pd}$ core-shell NPs. The finding reported the reduction potentials of $\mathrm{PdCl}_{4}{ }^{2-} / \mathrm{Pd}$ and $\mathrm{AuCl}^{4-} / \mathrm{Au}$ are 0.59 and $0.99 \mathrm{eV}$, respectively. As confirmed from the TEM analysis, during reaction the $\mathrm{Au}$ particles were synthesized earlier then Pd at different time intervals. This is highly consistent with $\mathrm{PdCl}_{4}{ }^{2-} / \mathrm{Pd}$ and $\mathrm{AuCl}^{4-} / \mathrm{Au}^{\prime}$ s redox potential difference, and it is believed that this difference is very important for the development of the core-shell NPs [34]. In the water-soluble components of geranium leaves, Shankar et al. [35] recognized proteins and secondary metabolites. They suggested that terpenoids aid in reducing silver ions, which are then oxidized to carbonyl groups. In a study with tamarind leaf broth, the probability of an acid (tartaric acid) functional group operating as a capping medium and being essential for forming bio-reduced gold nanoparticles was studied by Ankamwar et al. [36]. This study investigated the way that alfalfa roots can absorb silver from agar media in the form of $\mathrm{Ag}(0)$ and transmit it to the shooting segment in the identical oxidation number [37]. The synthesized nanoparticles' general characterization was carried out through scanning electron microscopy (SEM), transmission electron microscopy (TEM), energy-dispersive X-ray spectroscopy (EDX), ultraviolet-visible spectroscopy (UV-Vis), Fourier-transform infrared spectroscopy (FTIR) and X-ray diffraction (XRD). Microscopy (SEM and TEM) is used to determine the shape, size and particle aggregation of the desired nanoparticles without any comparison with standard materials [38]. Spectrometric techniques are the most widely used tactic for nanoparticle characterization. EDX is used to confirm the composition and distribution of the nanoparticles through spectrum and element mapping. The UV-Vis spectrometry investigates nanoparticles on the basis of particle aggregation and average particle size [39]. The basic principle of this method is absorption of plasmas by free electrons attached on the surface of nanoparticles. They interact with the electromagnetic field and shift towards higher wavelength values because the size of nanoparticles is directly proportional to higher values of wavelength. Furthermore, FTIR and XRD are applied for the determination of structural characteristics and crystallinity of formed particles.

The information on the production of various metallic NPs such as silver, gold, zinc, palladium and titanium using various plant extracts is summarized here.

\subsection{Silver Nanoparticles}

Silver nanoparticles (AgNPs) are commonly utilized nanoparticles and have attracted much study interest due to their distinctive properties. They are widely used in emerging biomedical and industrial applications [40]. AgNPs exhibit completely different characteristics from bulk materials derived from the same material due to their elevated surface/volume ratio [41]. In recent times, the synthesis of silver NPs by bio-organisms containing phytochemical agents has become an important goal for workers. Various unique secondary metabolites derived from plant extracts such as sugars, alkaloids, phenolic acids, flavonoids and terpenoids are responsible for bio-reducing ionic silver metal into nanoparticles $[25,42,43]$. 


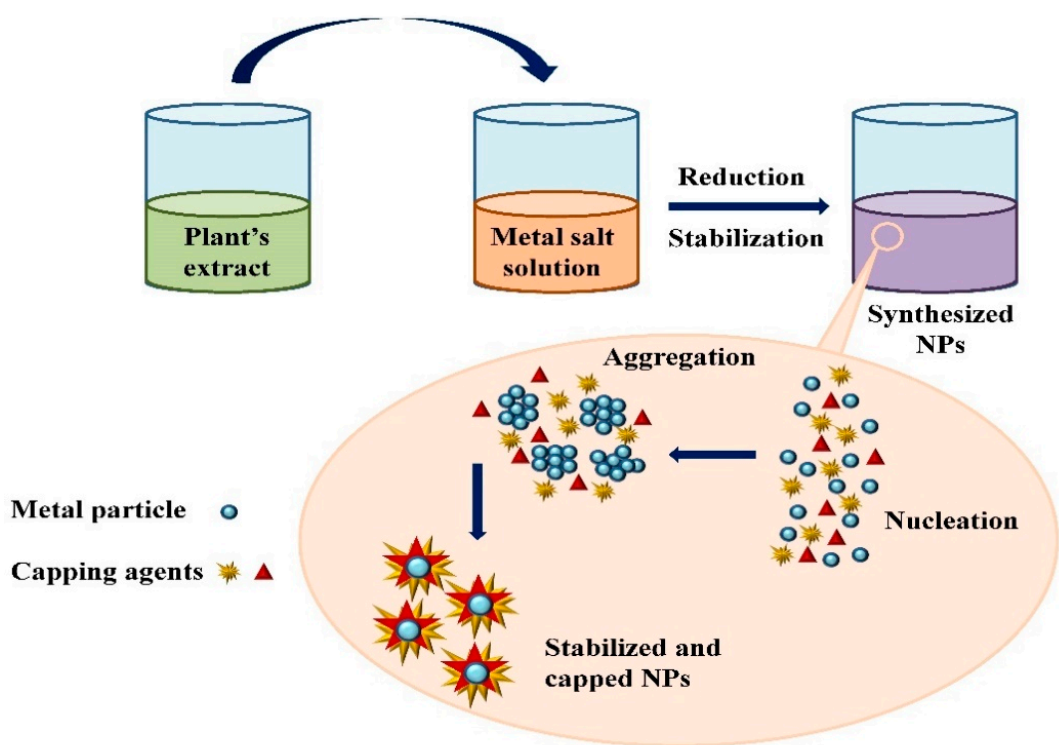

Figure 4. Mechanism of nanoparticle synthesis using phytoextracts.

Biosynthesis of AgNPs by Tribulus terrestris [44] and Astragalus tribuloides Delile [45] has already been reported. Spherical silver nanoparticles of size 2-6 $\mathrm{nm}$ were obtained from Cycas leaf [46]. For the synthesis of AgNPs, the affinity of Curcuma longa bark and powder extracts was determined. It was found that bark extract could produce more AgNPs than powder extract [47]. Kumar and Yadav [48] investigated Lonicera japonica plant leaf extract to develop silver and gold nanostructures. The particles obtained were different in size and shape; AgNPs were spherical to plate-like poly-shaped, and their size was $36-72 \mathrm{~nm}$. Banerjee and Narendhirakannan [49] utilized seed extract of Syzygium cumuni to form crystalline silver nanoparticles. There is considerable data available on how to make silver nanoparticles from the latex of the Plumeria rubra plant [50]. Ponarulselvam et al. [51] evaluated Catharanthus roseus to produce silver nanoparticles because of the presence of vincristine and vinblastin. Sathishkumar et al. [52] prepared silver nanoparticles using Cinnamomum zeylanicum bark extract and powdered bark extract and studied the variations in the biogenic nanoparticles.

AgNPs were synthesized with a 58-458 nm range in size from the leaf extract of Mukia maderaspatana [53]. Pedalium murex was also reported to synthesize AgNPs by Anandalakshmi et al. [54]. The TEM micrographs revealed that the produced AgNPs were circular with a mean value of $50 \mathrm{~nm}$. Raju et al. [55] utilized living peanut plants to synthesize AgNPs. The TEM examination showed that the biosynthesized AgNPs were of different shapes (spherical, hexagonal, triangular, square and rod-shaped) and sizes. Most of the formed AgNPs were spherical and $56 \mathrm{~nm}$ in average size. The EDX technique confirmed that the formed NPs were of silver. Some reports on plant-assisted synthesis of silver nanoparticles are enlisted below in Table 1.

Table 1. Plant-assisted synthesis of silver nanoparticles.

\begin{tabular}{ccccc}
\hline Plant Name & Parts Used & Size (nm) & Shapes & Reference \\
\hline Morinda citrifolia L. & Leaves, fruit pulp, seeds & $3-11$ & Spherical & Spherical \\
\hline Nymphae odorata & Leaves & $15 \pm 5$ & Spherical & [57] \\
\hline Capparis zeylanica & Leaves & 23 & Spherical & [58] \\
\hline Caesalpinia pulcherrima & Leaves & 9 & Spherical & [59] \\
\hline Carya illinoinensis & Leaves & $12-30$ & Spherical & [60] \\
\hline Mentha piperita & Leaves extract & 35 & & \\
\hline
\end{tabular}


Table 1. Cont.

\begin{tabular}{|c|c|c|c|c|}
\hline Plant Name & Parts Used & Size $(\mathrm{nm})$ & Shapes & Reference \\
\hline Jatropha curcas & Latex & $10-20$ & Face-centered cubic & [62] \\
\hline Acalypha indica & Leaves extract & $20-30$ & Spherical & [63] \\
\hline Hibiscus rosa sinensis & Leaves & 14 & Spherical/prism & [64] \\
\hline Cycas & Leaves & $2-6$ & Spherical & [46] \\
\hline Ceratonia siliqua & Leaves extract & $5-40$ & Spherical & [65] \\
\hline Suaeda monoica & Leaves & 31 & Spherical & [66] \\
\hline Catharanthtus roseus & Leaves & $35-55$ & Cubical & [51] \\
\hline Ocimum sanctum & Leaves extract & $10-20$ & Spherical & [67] \\
\hline Ocimum tenuiflorum & Leaves & $25-40$ & Spherical & [68] \\
\hline Ginkgo biloba & Leaves & $15-500$ & Cubic & [69] \\
\hline Tanacetum vulgare & Fruit & 16 & Spherical & [70] \\
\hline Argemone mexicana & Leaves extract & 30 & Spherical, hexagonal & [71] \\
\hline Sesuvium portulacastrum & Callus extract & $5-20$ & Spherical & [72] \\
\hline Syzygium cumini & Leaves and seed & $29-92$ & Spherical & {$[49,73]$} \\
\hline Cinnamomum camphora & Sun dried leaves & $3.2-20$ & Cubic hexagonal crystalline & [74] \\
\hline Melia azedarach & Leaves & 78 & Spherical & [75] \\
\hline Rhododedendron dauricam & Flower extract & $25-40$ & Spherical & {$[76]$} \\
\hline Lippia citriodora & Leaves extract & $15-30$ & Crystalline & {$[77]$} \\
\hline Tribulus terrestris & Fruit & $16-28$ & Spherical & [44] \\
\hline Citrullusm colocynthis & Leaves & 31 & Spherical & [78] \\
\hline
\end{tabular}

\subsection{Gold Nanoparticles}

Gold nanoparticles (AuNPs) are the most appealing new metal NPs due to their remarkable uses in catalysis, gene expression, nonlinear optics, nanoelectronics and disease diagnostics fields [79]. Gold nanoparticles made using either phytochemicals or other extract constituents are stable for a limited period [80]. According to Sharma et al. [81], tea leaf extract can be employed in gold NP preparation. Suman et al. [82] synthesize gold NPs of size range 8-17 $\mathrm{nm}$ from the root extracts of Morinda citrifolia at ambient temperature. The biogenic production of gold nanoparticles exploiting Nyctanthes arbortristis alcoholic extract led to the creation of spherical-shaped nanostructures of size $19.8 \pm 5.0 \mathrm{~nm}$ [83]. The synthesis of AuNPs was reported with Bael (Aegle marmelos) leaves and the particles obtained were round and 4-10 $\mathrm{nm}$ in size [84].

Lee et al. [38] performed the synthesis of AuNPs from the peel aqueous extract of Garcinia mangostana. The aqueous solution of gold in contact with G. mangostana extract was reduced to gold metal ions and synthesized AuNPs. The FTIR results suggested that the reducing agent found in the aqueous solution of G. mangostana is strongly associated with anthocyanins, benzophenones, flavonoids and phenols. The synthesized AuNPs were spherical with a size range of $32.96 \pm 5.25 \mathrm{~nm}$ that was analyzed by TEM. Rodríguez-León et al. [85] synthesized AuNPs from the bark extract of Mimosa tenuiflora at different metallic (acting as precursor) concentrations.

AuNPs were made from the aqueous suspension of Azadirachta indica [86]. When the $A$. indica extract was mixed with $\mathrm{Au}(\mathrm{III})$ solution, the nanoparticle formation commenced. Kasthuri et al. [87] constructed gold nanoparticles with triangular and hexagonal shapes from $\mathrm{HAuCl}_{4}$ solution and a diluted extract possessing phyllanthin (derived from Phyllanthus amarus). Aromal and Philip [88] synthesized AuNPs using Benincasa hispida seed extract as either a reducing or capping agent. Carboxylic groups $(\mathrm{COOH})$ found in the 
plant extract change to $\mathrm{COO}^{-}$during the reduction process. The protein's $\mathrm{COOH}$ group works as a surfactant, adhering to the surface of the AuNPs and then stabilizing AuNPs via electrostatic stabilization. The synthesized AuNPs were observed to have a crystalline nature and were $10-30 \mathrm{~nm}$ in size. Some reports on the plant-assisted synthesis of gold nanoparticles are listed below in Table 2.

Table 2. Plant-assisted synthesis of gold nanoparticles.

\begin{tabular}{|c|c|c|c|c|}
\hline Plant Name & Parts Used & Size $(\mathrm{nm})$ & Shapes & Reference \\
\hline Parkia biglobosa & Leaves & $1-35$ & Truncated, pentagonal, spherical, triangular & [39] \\
\hline Curcuma pseudomontana & Rhizome & 20 & Spherical & [89] \\
\hline Lawsonia inermis & Leaves & 20 & Spherical & [90] \\
\hline Cinnamon & Bark & 35 & Spherical & [91] \\
\hline Croton Caudatus Geisel & Leaves & 20 & Spherical & [13] \\
\hline Tamarind & Leaves & $20-40$ & Triangle & [36] \\
\hline Aloe vera & Plant extract & $50 / 350$ & Crystalline & [92] \\
\hline Mentha, Ocimum, Eucalyptus & Leaves & $3-16$ & Spherical & [93] \\
\hline Canna indica, Quisqualis indica & Leaves and flower & $30-130$ & Polymorphic/stable & {$[94]$} \\
\hline Murraya koenigii & Leaves & 20 & Spherical & [95] \\
\hline Aegle marmelos & Leaves & $4-10$ & Spherical & [84] \\
\hline Rosa hybrid & Rose petals & 10 & Cubic & [96] \\
\hline Terminalia chebula & Plant extract & $6-60$ & Anisotropic & [97] \\
\hline Momordica charantia & Fruit & $30-40$ & Cubical & [98] \\
\hline Phyllanthus amarus & Leaves & $65-99$ & Cubic & [99] \\
\hline Mangifera indica & Leaves & $17-20$ & Spherical & [100] \\
\hline Stevia rebaudiana & Leaves & $8-20$ & Octahedral & [101] \\
\hline Nyctanthes arbortristis & Flower extract & 19.8 & Spherical, hexagonal & [83] \\
\hline Trigonella foneum-graecum & Leaves & $15-25$ & Spherical & [79] \\
\hline Tanacetum vulgare & Fruit & 11 & Triangular & {$[70]$} \\
\hline Cuminum cyminum & Seeds & $1-10$ & Spherical & [102] \\
\hline Sorbus aucuparia & Leaf extract & $16-18$ & Spherical, triangular, hexagonal & [103] \\
\hline
\end{tabular}

\subsection{Zinc Nanoparticles}

Zinc oxide $(\mathrm{ZnO})$ is an inorganic metal oxide with a vast range of nanostructures. Zinc nanoparticles (ZnNPs) have gained considerable attention due to their low cost, large surface area, white appearance, UV-filtering, antifungal, antibacterial and photochemical properties, and high catalytic activity $[104,105]$. There are several reports of $\mathrm{ZnO}$ nanoparticle synthesis using various plant extracts [106-109]. Plant extracts contain some phytochemicals (i.e., polyphenols, saponins, terpenoids) that act as reducing and stabilizing agents in the reaction system. Phytochemicals are synthesized in the plant parts, including root, stem, leaf, fruit and seed. These phytochemicals lower the metal's valence to zero, then calcinate it to add oxide. Additionally, zinc ions interact with the polyphenols in the plant extract to form a complex. After that, zinc hydroxide $\left(\mathrm{Zn}(\mathrm{OH})_{2}\right)$ is formed via hydrolysis, and then $\mathrm{ZnO}$ nanoparticles are synthesized after complex calculations [110].

During the literature survey, it was observed that members of the Fabaceae, Rutaceae, Apocynaceae, Solanaceae and Lamiaceae families are most commonly employed for the production of ZnNPs (Table 3). Plants from the family Lamiaceae, such as Anisochilus carnosus, Plectranthus amboinicus and Vitex negundo were used to produce $\mathrm{ZnO}$ nanoparticles of different sizes and shapes, including hexagonal, spherical, quasi-spherical and 
rod-shaped particles. The findings indicated that the particle sizes decrease when plant extract concentration increases [111,112]. All experiments displayed nanoparticles in the same size range with spherical and hexagonal disc shapes, which XRD and TEM analysis characterized. Singh et al. [113] synthesized ZnO NPs using Calotropis procera latex that were spherical and $5 \mathrm{~nm}$ to $40 \mathrm{~nm}$ in size. Ramesh et al. [114] used the floral extract of Cassia auriculata to react with $\mathrm{Zn}\left(\mathrm{NO}_{3}\right)_{2}$ solution resulting in the development of $\mathrm{ZnNPs}$ with a particle size ranging from $110 \mathrm{~nm}$ to $280 \mathrm{~nm}$. Some reports on the plant-assisted synthesis of zinc nanoparticles are listed below in Table 3.

Table 3. Plant-assisted synthesis of zinc nanoparticles.

\begin{tabular}{|c|c|c|c|c|}
\hline Plant Name & Parts Used & Size $(\mathrm{nm})$ & Shapes & Reference \\
\hline Artemisia pallens & Leaves along with stem & 50-100 & Hexagonal & [109] \\
\hline Cayratia pedata & Leaves & 52.24 & Spherical & [115] \\
\hline Euphorbia hirta & Leaves & $20-50$ & Spherical & [116] \\
\hline Eucalyptus globules & Leaves & $52-70$ & Spherical, elongated & [108] \\
\hline Tecoma castanifolia & Leaves & $70-75$ & Spherical & [117] \\
\hline Zingiber officinale & Root & $30-50$ & Spherical & [118] \\
\hline Azadirachta indica & Leaves & 50 & Spindle shaped & [119] \\
\hline Catharanthus roseus & Leaves & $23-57$ & Spherical & [120] \\
\hline Solanum nigrum & Leaves & $20-30$ & Hexagonal & [121] \\
\hline Olea europea & Leaves & $18-30$ & Crystalline & [122] \\
\hline Azadirachta indica & Leaves & 25 & Crystalline & [123] \\
\hline Nyctanthes arbor-tristis & Flowers & $12-32$ & Crystalline & [124] \\
\hline Hibiscus rosa-sinensis & Leaves & $30-35$ & Crystal, spongy & [125] \\
\hline Ruta graveolens & Stem & 28 & Spherical & [106] \\
\hline Aloe vera & Leaves & 22.18 & Hexagonal & [126] \\
\hline Ocimum tenuiflorum & Leaves & $11-25$ & Hexagonal & [127] \\
\hline Sargassum muticum & Leaves & $30-57$ & Hexagonal & [128] \\
\hline Calotropis gigantea & Leaves & $1.5-8.5$ & Spherical & [107] \\
\hline Beta vulgaris & Root & $52-76$ & Hexagonal & [129] \\
\hline Curcuma longa & Root & $20-80$ & Hexagonal & [130] \\
\hline Nephelium lappaceum & Peel & 20 & Spherical & [131] \\
\hline Artocarpus gomezianus & Fruit & 50 & Spherical & [132] \\
\hline Senna auriculata & Leaves & 2 & Spherical & [133] \\
\hline Brassica oleraceae & Leaves & $1-100$ & Spherical and sheet shaped & [134] \\
\hline Acalypha Indica & Leaves & 100-200 & Cube & [135] \\
\hline Plectranthus amboinicus & Leaves & $20-50$ & Crystalline & [136] \\
\hline Coptidis rhizome & Rhizome & $2.9-25.2$ & Spherical and rod shaped & [137] \\
\hline Ginger & Rhizome & $23-26$ & Crystalline & [138] \\
\hline
\end{tabular}

\subsection{Titanium Nanoparticles}

Titanium dioxide nanoparticles (TiNPs) have drawn great attention because of their appropriate electrical band structure, high specific surface area and quantum efficacy, stability, and chemical innerness [139]. TiNPs have a wide applicability in lowering the toxicity of synthetic dyes [140] and pharmaceutical medicines [141], wastewater treatment [142], etc. The synthesis of $\mathrm{TiO}_{2}$ nanoparticles on a wide scale using biological methods has 
stimulated the interest of researchers due to its low cost, environmental friendliness and reproducibility. Nowadays, there are many reports on the biosynthesis of $\mathrm{TiO}_{2}$ nanoparticles by using microbes (such as bacteria and fungi), algae, plant parts and enzymes. The aqueous extract of Eclipta prostrata produce nanoparticles with a spherical shape and sizes ranging from $36 \mathrm{~nm}$ to $68 \mathrm{~nm}$, confirmed by XRD and TEM analysis [143]. Subhashini and Nachiyar [144] used the leaf extract of Albizia saman for the production of titanium NPs via a green route. The aqueous $\mathrm{TiO}_{2}$ solution was added dropwise into the leaf extract with stirring at $50{ }^{\circ} \mathrm{C}$ resulting in the formation of anatase crystals of $\mathrm{TiO}_{2}$ nanoparticles. The synthesized $\mathrm{TiO}_{2}$ nanoparticles were found to be $41 \mathrm{~nm}$ in size and confirmed by XRD analysis. Jalill et al. [145] synthesized the anatase form of $\mathrm{TiO}_{2}$ nanoparticles by using the plant extract of Curcuma longa (because of its terpenoid and flavonoid contents). The nanoparticles that were developed were identified by the techniques of XRD, FTIR, SEM and EDX that revealed the aggregated, circular structure and a particle size of 160-220 nm. TiNPs were synthesized by the utilization of herbal extract (as a bio-reductant) of Echinacea purpurea [146]. The particle size of the synthesized $\mathrm{TiO}_{2}$ nanoparticles was found to be in the $120 \mathrm{~nm}$ range. The leaf extract of Psidium guajava includes alcohol and primary and aromatic amines, which aid in producing $\mathrm{TiO}_{2}$ nanoparticles. Some reports on the plant-assisted synthesis of titanium nanoparticles are listed below in Table 4.

Table 4. Plant-assisted synthesis of titanium nanoparticles.

\begin{tabular}{|c|c|c|c|c|}
\hline Plant Name & Parts Used & Size (nm) & Shapes & Reference \\
\hline Ledebouria revoluta & Bulb & 47 & Tetragonal & [147] \\
\hline Pouteria campechiana & Leaves & 73-140 & Spherical & [148] \\
\hline Syzygium cumini & Leaves & 22 & Spherical round & [149] \\
\hline Mentha arvensis & Leaves & $20-70$ & Spherical & [150] \\
\hline Azadirachta indica & Leaves & $15-50$ & Spherical & [151] \\
\hline Psidium guajava & Leaves & 32.58 & Spherical & [152] \\
\hline Nyctanthes arbor-tristis & Leaves & $100-150,100-200$ & Cubic, crystalline, Spherical & [153] \\
\hline Calotropis gigantea & Flower & $10-52$ & Crystalline, Spherical oval & [154] \\
\hline Salvia officinalis & Leaves & $15-20$ & Spherical & [140] \\
\hline Solanum trilobatum & Leaves & 70 & Spherical, oval & [155] \\
\hline Azadirachta indica & Leaves & 124 & Spherical & [156] \\
\hline Annona squamosal & Leaves & $40-60$ & Spherical & [157] \\
\hline $\begin{array}{c}\text { Jatropha curcas, citrus } \\
\text { aurantium }\end{array}$ & Leaves & $25-50$ & Spherical & [158] \\
\hline Jatropha curcas & Latex & $25-50$ & Spherical, uneven & [159] \\
\hline Euphorbia prostrata & Leaves & $81-84$ & Spherical & [160] \\
\hline Citrus sinensis & Fruit peel & 19 & Tetragonal & [161] \\
\hline Cassia auriculata & Leaves & 38 & Spherical & [162] \\
\hline Ocimum basilicum & Leaves & 50 & Hexagonal & [163] \\
\hline Hibiscus-rosa-sinensis & Petals & $7-24$ & Spherical & [12] \\
\hline Erythrina variegates & Leaves & 39 & Crystalline, spherical & [164] \\
\hline
\end{tabular}

\subsection{Palladium Nanoparticles}

The major studies of most researchers were focused on the biological synthesis of palladium nanoparticles (PdNPs) via plant materials because it is cost-effective, sustainable, and human- and eco-friendly. Plant extracts contain a number of primary and secondary metabolites that transform metal (Pd) salts to PdNPs. Siddiqi and Husen [165] reported 
that the shape, size and stability of PdNPs depends on concentrations of plant extract, $\mathrm{pH}$, temperature and incubation time. Plant sources including the extracts of leaves, flowers, seeds, fruits, peels and roots were extensively utilized to synthesize Pd nanoparticles.

Gurunathan et al. [166] synthesized Pd nanoparticles from a plant extract of Evolvulus alsinoides. This plant extract has various natural antioxidants, including alkaloids, flavonoids, saponins, tannin, steroids and phenol, which work as reducing and capping tools to synthesize Pd nanoparticles. Nasrollahzadeh et al. [167] used the leaf extract of Hippophae rhamnoides to synthesize PdNPs because the leaf extract has polyphenols that play an important role as reducing and capping agents for nanostructure development. The formed NPs were found to be spherically shaped and ranging from $2.5 \mathrm{~nm}$ to $14 \mathrm{~nm}$, which was confirmed by TEM. Pd nanoparticles have been synthesized from the root extract of Salvadora persica, which contains polyphenols that act as reductant and stabilizing agents [168]. The average particle size of synthesized NPs was $10 \mathrm{~nm}$ at $90^{\circ} \mathrm{C}$, which was revealed from the UV spectrum of the colloidal solution. Palladium NPs were generated with the bark extract of Cinnamomum zeylanicum and $\mathrm{PdCl}_{2}$ solution at $30{ }^{\circ} \mathrm{C}$ [169]. Khan et al. [170] carried out the plant-assisted synthesis of PdNPs from the extract of Pulicaria glutinosa and $\mathrm{PdCl}_{2}$. After stirring the mixture of $\mathrm{PdCl}_{2}+$ extract at $90{ }^{\circ} \mathrm{C}$ for $2 \mathrm{~h}$, the colour changed from pale yellow to dark brown, indicating the production of PdNPs, validated by UVvisible spectroscopy. A TEM monograph revealed the particle size of the obtained Pd nanoparticles ranged between $20 \mathrm{~nm}$ and $25 \mathrm{~nm}$. The particle size of the synthesized NPs was found to be between $10 \mathrm{~nm}$ and $50 \mathrm{~nm}$. The biosynthesis of Pd nanoparticles from the leafy solution of Glycine max has been reported [171]. The shape of the particles was found to be uniformly spherical with a $15 \mathrm{~nm}$ diameter, which was confirmed by TEM micrograph. Jia et al. [172] performed the synthesis of Pd nanoparticles utilizing Gardenia jasminoides extract containing various antioxidants such as geniposide, crocins, crocetin and chlorogenic acid, which reduce and stabilize the nanoparticles. There are some reports on plant-assisted synthesis of palladium nanoparticles listed below in Table 5 .

Table 5. Plant-assisted synthesis of palladium nanoparticles.

\begin{tabular}{|c|c|c|c|c|}
\hline Plant Name & Parts Used & Size (nm) & Shapes & Reference \\
\hline Peganum harmala & Seed & $22.5 \pm 5.7$ & Spherical & [173] \\
\hline Coleus amboinicus & Leaves & $40-50$ & Spherical & [174] \\
\hline Anogeissus latifolia & Gum ghatti & $4.8 \pm 1.6$ & Spherical & [175] \\
\hline Filicium decipiens & Leaves & $2-22$ & Spherical & [176] \\
\hline Cinnamomum camphora & Leaves & $3.2-6$ & Multiple & [177] \\
\hline Pulicariaglutinosa & Leaves & $3-5$ & Spherical & [170] \\
\hline Musa paradisica & Peeled banana & 50 & Crystalline & [178] \\
\hline Cinnamom zeylanicum & Bark & $15-20$ & Crystalline & [169] \\
\hline Catharanthus roseus & Leaves & 38 & Spherical & [179] \\
\hline Curcuma longa & Tuber & $10-15$ & Spherical & [180] \\
\hline Glycine max & Leaves & 15 & Spherical & [171] \\
\hline
\end{tabular}

\section{Factors Affecting Plant-Assisted Synthesis of Nanoparticles}

During the biosynthesis of nanoparticles, the major difficulties often faced are maintaining the structure and size of particles in addition to obtaining mono-dispersity in the solution phase. Nevertheless, these problems can be solved by monitoring development factors, namely $\mathrm{pH}$, temperature and incubation time (Figure 5). 


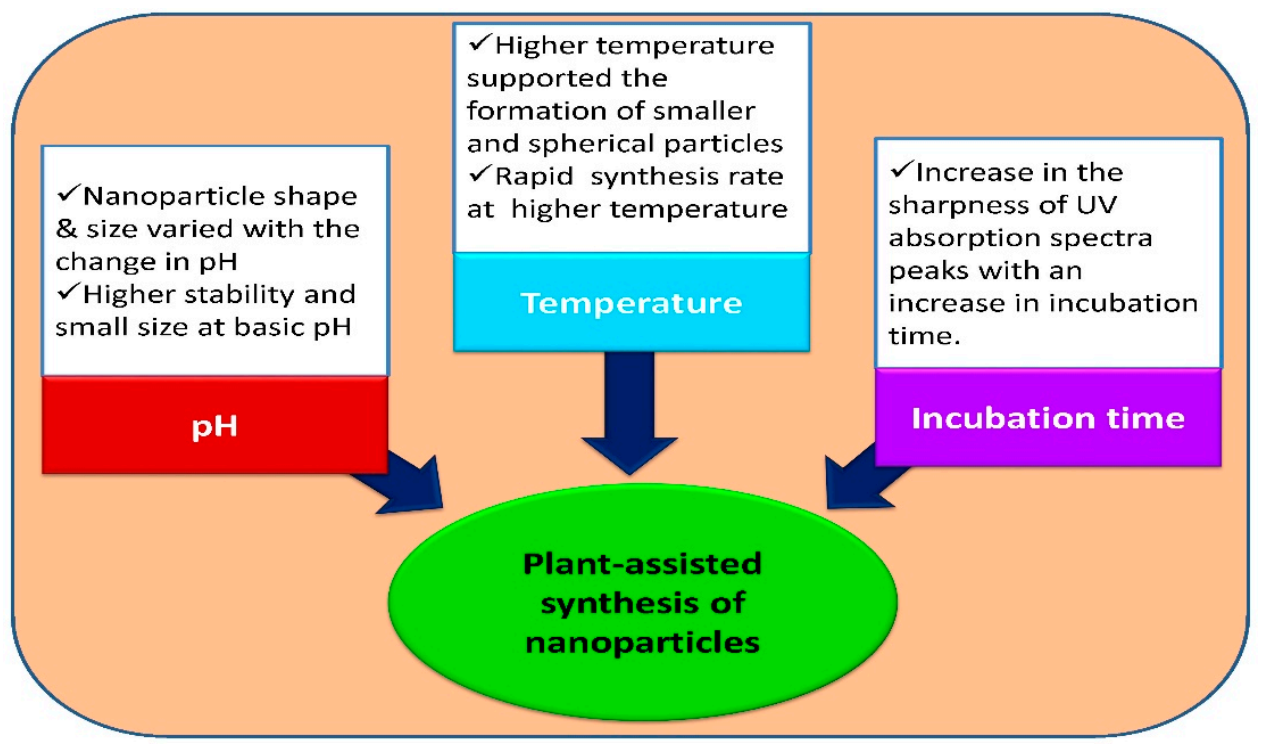

Figure 5. Factors affecting plant-assisted synthesis of nanoparticles.

\subsection{Effect of $p H$}

Several scientists have reported that $\mathrm{pH}$ plays a crucial role in nanoparticles' biological synthesis. Muthu and Priya [181] studied the way that pH is an essential element for the plant-assisted preparation of silver nanoparticles and found that the size of nanoparticles increases with the decrease in $\mathrm{pH}$. In this investigation the intensity of the surface plasmon resonance (SPR) peak increases with a successive rise in $\mathrm{pH}$ from 3 to 9 and the rate of the generation of silver NPs is greater at $\mathrm{pH}=9$. This shows the alkaline $\mathrm{pH}$ significantly enhances the reducing and stabilizing potential of Ficus hispida leaf extract in the formation of AgNPs. The number of formed silver NPs increased with higher $\mathrm{pH}$ because of the increased reaction rate of the leaf extract of the test plant and thus NPs with a small particle size were observed [182]. Armendariz et al. [183] stated that the size of gold NPs prepared from Avena sativa extract was directly $\mathrm{pH}$-dependent. The experiment conducted by $\mathrm{Zul}$ fiqar et al. [184] reported the stability of the biosynthesized silver nanoparticle colloid at $\mathrm{pH}$ 4. Another study reported that alakaline $\mathrm{pH}(8)$ at room temperature results in the formation of diverse-shaped gold NPs from the leaf extracts of Angelica archangelica, Hypericum perforatum and Hamamelis virginiana with sizes ranging from 4 to $8 \mathrm{~nm}$ in diameter [185]. Dhamecha et al. [186] observed that red to dark purple color gold NPs were formed depending upon the $\mathrm{pH}$. NPs with a purple colour were produced at $\mathrm{pH} 7$, a fluorescent purple colour at $\mathrm{pH} 10$ and no colour was noticed in acidic $\mathrm{pH}$ 2. Sathishkumar et al. [169] tested the $\mathrm{pH}$ effect over a broader range (1-11) in Cinnamom zeylanicum and bark-extractsynthesized silver nanoparticles. They found, after the synthesis of silver NPs, a drop in the $\mathrm{pH}$ of the solution in most cases. Dubey et al. [70] observed that AgNPs had a reduced zeta potential value $(-26 \mathrm{mV})$ in highly acidic $\mathrm{pH}$ solutions than at alkaline $\mathrm{pH}$, indicating that nanoparticles at basic $\mathrm{pH}$ are more stable and smaller in size. At $\mathrm{pH} 8$, the colloid consists of nanoparticles of approximately $20 \mathrm{~nm}$ in size, with triangular, hexagonal and nearly spherical shapes. In the present study the average size of AgNPs at $\mathrm{pH} 4$ was $32.7 \mathrm{~nm}$ and they were spherical in shape. As the $\mathrm{pH}$ of the reaction increased to 7 , the mean size of the NPs decreased to $7.12 \mathrm{~nm}$. This shows a direct relation between the $\mathrm{pH}$ of the extract and nanoparticle size [187]. Silva-De-Hoyos et al. [188] observed that high pH, i.e., 7.8, led to the development of AuNPs with a size of 11-20 nm.

\subsection{Temperature Role in Plant-Assisted Synthesis}

In most studies, regarding the influence of the reaction temperature, it was evaluated that the size of nanostructures is inversely proportional to the temperature. At room temperature $\left(27^{\circ} \mathrm{C}\right)$, NPs with a mean size of $49.91 \mathrm{~nm}$ and distorted spherical shape 
were found. As the temperature increases moderately to $45^{\circ} \mathrm{C}$, the size of silver NPs starts reducing to $33.61 \mathrm{~nm}$, with a more uniform spherical shape [187]. Fayaz et al. [189] also reported that the size of the NPs decreases at higher temperatures and increases at lower temperatures. Silver nanoparticles using olive leaf extract were synthesized by Khalil et al. [190]. They found that on increasing the temperature, there was a quick reduction of $\mathrm{Ag}^{+}$ions and the simultaneous uniform nucleation of silver nuclei allowing the formation of nanoparticles of a small size. At high temperatures, a higher reduction rate was observed because of the utilization of silver ions in nuclei production, whereas the secondary reduction was halted over the surface of predetermined nuclei [69]. Similarly, the intensity of the SPR peak was increased with elevation in temperature. The enhanced reaction temperature causes faster reduction of the $\mathrm{Ag}^{+}$ions and successive homogeneous nucleation of Ag NPs results in production of small sized particles. When the temperature changes from 35 to $90^{\circ} \mathrm{C}$, the intensity of the SPR peak is also shifted to high. Further temperature rises above $90{ }^{\circ} \mathrm{C}$ result in decreased intensity of the SPR peak and hence $90^{\circ} \mathrm{C}$ is considered as the optimum temperature for AgNP synthesis [182]. Song et al. [191] studied the role of temperature on the formation of nanoparticles. They found that a high temperature favored the formation of small and spherical particles, whereas, at a lower temperature, polydispersed particles of size 5-300 $\mathrm{nm}$ were extracted.

\subsection{Contact or Incubation Role in Plant-Assisted Synthesis}

Many scientists have worked on nanoparticle synthesis and showed the effect of the incubation period. Bar et al. [62] evaluated the impact of reaction time on synthesis of AgNPs using the optimized concentration of $\mathrm{AgNO}_{3}(0.005 \mathrm{M})$ and latex extract $(3 \%)$ of Jatropha curcas. It was observed that the intensity of SPR peaks increases as the reaction time proceeds and after $4 \mathrm{~h}$ of incubation period, two SPR bands separated by more than $50 \mathrm{~nm}$ were achieved. Philip [192] suggested that in a plant-mediated synthesis, silver nanoparticles' size was dependent on the contact time. Ghoreishi et al. [193] also documented the importance of an appropriate reaction time in the stable synthesis of gold and silver NPs with Rosa damascena. While dealing with Chenopodium leaf extract, the authors of [194] observed a clear rise in the peaks of UV absorption spectra on increasing contact time. They obtained nanoparticles within 15 min of the reaction and these kept rising for about $2 \mathrm{~h}$, but a slight deviation was observed after it. Likewise, Dubey et al. [70] noted that the synthesis of Au and Ag NPs was initiated after 10 min of the reaction in Tansy fruit-mediated synthesis. The UV-Vis spectral analysis showed enhancement in the absorbance intensity of the reaction mixture with incubation time, which consequently resulted in solution stability after $24 \mathrm{~h}$ of exposure, indicating the successful synthesis of silver nanoparticles [195].

\section{Application of Nanoparticles}

Nanotechnology has attracted researchers' interest because of the microscopic size and high surface-to-volume ratio of nanoparticles, which results in chemical and physical changes in the characteristics. Due to these properties, nanoparticles have a great variety of applications in several biomedical, environmental and agricultural sectors.

Hydrophilic (water-soluble) nanoparticles have been employed as drug carriers for many years. The most efficient nanoparticles used for this purpose are polyethylene oxide nanoparticles [27]. Their ability to deliver drugs in an optimum range has enhanced therapeutic efficiency and patient compliance. Among the metal nanoparticles, Au, Ag and Fe NPs have been widely used in medical applications. AuNPs are used in drug delivery, bioimaging and photothermal therapy [196], whereas AgNPs are used for drug delivery, wound dressing, cancer therapy and to restrict the growth of microbial infection [197]. ZnNPs have recently been applied as antimicrobial and anticancer agents due to their potential to generate reactive oxygen species [197], and nanoparticles synthesized using copper have also been used in a wide range of biomedical applications [198,199]. Similarly, nanoparticles 
of iron, gold, silver, copper, zinc and titanium are applied as antimicrobial agents to inhibit the growth of infectious bacteria and fungus and thus induce mortality $[29,30]$.

In the environment sector, due to the ratio of surface area to mass, nanoparticles play a very important role in the purification of water through binding with precipitates, debris and heavy metals [200]. This binding depends on the composition, morphology and absorbency of the nanoparticles. Nanoparticles are applied in the field of environment in three different ways. Firstly, making environment-friendly products through green chemistry to avoid pollution [201]. Secondly, the bioremediation of environmental contaminants [202]. Thirdly, nanoparticles are used as sensors to identify changes in environmental stages [142,203]. $\mathrm{TiO}_{2}$ nanoparticles are an effective photocatalytic agent used in water treatment. The use of these nanoparticles to filter out the organic contaminants from several water reservoirs has been explored [204]. FeNPs have gained attention because of their potency to bioremediate heavy metals, namely lead, mercury, arsenic, cadmium and thallium from water [205]. In addition to bioremediation, photo-degradation by $\mathrm{NiO}$ and $\mathrm{ZnO}$ nanoparticles has also been accomplished [206,207]. The efficient photo-degradation was due to nano-sized nanoparticles (10-50 nm) [208].

Nanoparticles have many potential applications in the field of agriculture due to their antimicrobial activity. In the agriculture sector, nanoparticles are used as nano-formulations of agrochemicals to be applied as pesticides and fertilizers for crop improvement, nanosensors for recognizing diseases to protect the crop and nano-devices for genetic engineering of plants. The agricultural applications of antimicrobial nanomaterials have increased since the last decade. Silver nanoparticles have been found to be very effective against Bacillus cereus, Staphylococcus aureus, Shigella flexneri and Escherichia coli [45]. Similarly, antimicrobial activity has also been reported for several other green-synthesized nanoparticles, including gold, zinc, titanium and palladium [89,109,148,176]. An overview of nanotechnology applications in agriculture is presented in Figure 6.

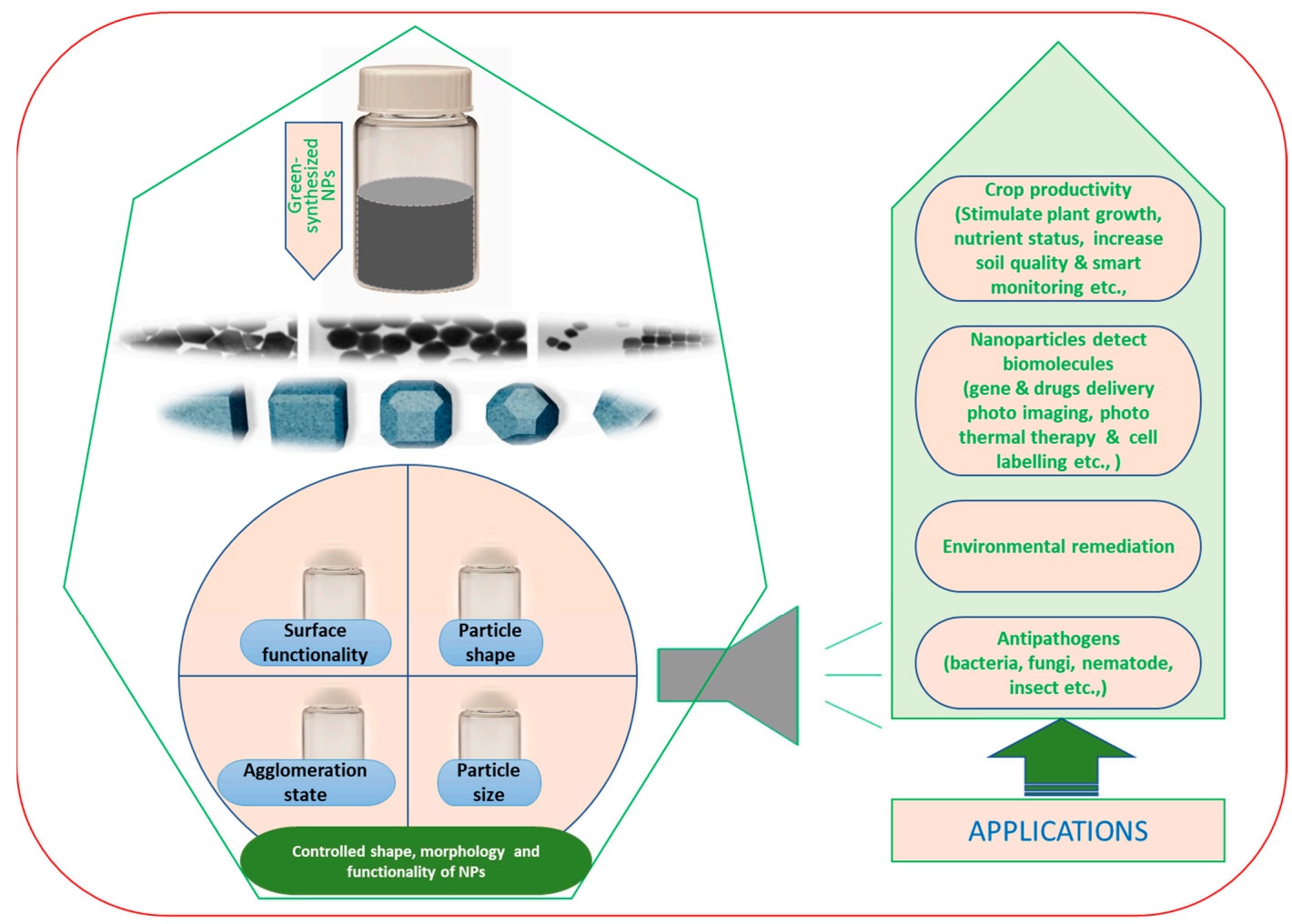

Figure 6. An overview diagram shows synthesized nanoparticles (NPs) produced via the green route for various biological applications. The different sizes, shapes and surface bio-functionalized NPs are developed in a controlled way for the target application. 
At present, green-synthesized metal nanoparticles are viewed as powerful nanotechnology to manage hazardous soil-borne microbes. Many green-synthesized metal nanoparticles have been explored for their antimicrobial properties. These include silver, iron, copper, silicon, silica, graphene, gold, palladium, zinc oxide, titanium dioxide, selenium oxide and carbon nanotubes. Currently, the application of green nanoparticles is being encouraged to manage plant-parasitic nematodes as they have a multisite mode of action and no phytotoxicity (Figure 6).

\section{Conclusions and Future Roles}

The traditional nanoparticle synthesis approaches are expensive and generate potentially toxic substances; it is necessary to reduce the risk of contamination from the various chemicals used during chemical and physical methods. The generation of nanoparticles using extracts of different plant species, or green synthesis, has emerged as an important front in nanotechnology. Furthermore, plant extracts are readily available to develop an efficient and healthy green route for the scale-up and industrial development of well-dispersed metallic nanoparticles.

This review emphasizes recent research findings in novel metal nanoparticle plantassisted synthesis and critically examines the various mechanisms proposed to explain it. The plant-assisted synthesis of metal NPs derived from plant extracts has multiple positive aspects: eco-friendliness, biocompatibility and cost-effectiveness. Researchers have prioritized the investigation of the biochemical pathways and enzymatic reactions of nanomaterials biosynthesis, as well as the identification and characterization of biomolecules associated with nanoparticle synthesis. Research is an ongoing operation, with researchers from different fields regularly contributing more substantial solutions to the significant problems.

Author Contributions: F.K., M.S. and M.A.—conceptualization and writing; F.A. and P.M.-review and editing; F.A. and M.A.S.- -visualization and supervision. All authors have read and agreed to the published version of the manuscript.

Funding: We thank the University Grants Commission for financial support (UGC-BSR Research Start-up-Grant: F30-409/2018).

Institutional Review Board Statement: Not applicable.

Informed Consent Statement: Not applicable.

Data Availability Statement: Not applicable.

Conflicts of Interest: The authors declare no conflict of interest.

\section{References}

1. Sergeev, G.B.; Shabatina, T.I. Cryochemistry of nanometals. Colloids Surf. A Physicochem. Eng. Asp. 2008, 313-314, 18-22. [CrossRef]

2. Duan, H.; Wang, D.; Li, Y. Green chemistry for nanoparticle synthesis. Chem. Soc. Rev. 2015, 44, 5778-5792. [CrossRef]

3. Korbekandi, H.; Iravani, S.; Abbasi, S. Production of nanoparticles using organisms Production of nanoparticles using organisms. Crit. Rev. Biotechnol. 2009, 29, 279-306. [CrossRef]

4. Luangpipat, T.; Beattie, I.R.; Chisti, Y.; Haverkamp, R.G. Gold nanoparticles produced in a microalga. J. Nanopart. Res. 2011, 13, 6439-6445. [CrossRef]

5. Arumugam, A.; Karthikeyan, C.; Haja Hameed, A.S.; Gopinath, K.; Gowri, S.; Karthika, V. Synthesis of cerium oxide nanoparticles using Gloriosa superba L. leaf extract and their structural, optical and antibacterial properties. Mater. Sci. Eng. C 2015, 49, 408-415. [CrossRef] [PubMed]

6. Mehata, M.S. Enhancement of Charge Transfer and Quenching of Photoluminescence of Capped CdS Quantum Dots. Sci. Rep. 2015, 5, 12056. [CrossRef] [PubMed]

7. Shetti, N.P.; Bukkitgar, S.D.; Reddy, K.R.; Reddy, C.V.; Aminabhavi, T.M. Nanostructured titanium oxide hybrids-based electrochemical biosensors for healthcare applications. Colloids Surf. B Biointerfaces 2019, 178, 385-394. [CrossRef]

8. Zhang, M.; Yuan, P.; Zhou, N.; Su, Y.; Shao, M.; Chi, C. pH-Sensitive N-doped carbon dots-heparin and doxorubicin drug delivery system: Preparation and anticancer research. RSC Adv. 2017, 7, 9347-9356. [CrossRef]

9. Niculescu, A.G.; Chircov, C.; Bîrcă, A.C.; Grumezescu, A.M. Nanomaterials Synthesis through Microfluidic Methods: An Updated Overview. Nanomaterials 2021, 11, 864. [CrossRef] 
10. Chung, I.M.; Park, I.; Seung-Hyun, K.; Thiruvengadam, M.; Rajakumar, G. Plant-Mediated Synthesis of Silver Nanoparticles: Their Characteristic Properties and Therapeutic Applications. Nanoscale Res. Lett. 2016, 11, 1-14. [CrossRef] [PubMed]

11. El-Khatib, A.M.; Badawi, M.S.; Ghatass, Z.F.; Mohamed, M.M.; Elkhatib, M. Synthesize of Silver Nanoparticles by Arc Discharge Method Using Two Different Rotational Electrode Shapes. J. Clust. Sci. 2018, 29, 1169-1175. [CrossRef]

12. Kumar, P.S.M.; Francis, A.P.; Devasena, T. Biosynthesized and Chemically Synthesized Titania Nanoparticles: Comparative Analysis of Antibacterial Activity. J. Environ. Nanotechnol. 2014, 3, 73-81.

13. Kumar, P.V.; Kala, S.M.J.; Prakash, K.S. Green synthesis of gold nanoparticles using Croton Caudatus Geisel leaf extract and their biological studies. Mater. Lett. 2019, 236, 19-22. [CrossRef]

14. Chen, Y.H.; Yeh, C.S. Laser ablation method: Use of surfactants to form the dispersed Ag nanoparticles. Colloids Surf. A Physicochem. Eng. Asp. 2002, 197, 133-139. [CrossRef]

15. Sen, P.; Ghosh, J.; Abdullah, A.; Kumar, P. Preparation of $\mathrm{Cu}, \mathrm{Ag}, \mathrm{Fe}$ and $\mathrm{Al}$ nanoparticles by the exploding wire technique J. Chem. Sci. 2003, 115, 499-508. [CrossRef]

16. Sangar, S.; Sharma, S.; Vats, V.K.; Mehta, S.K.; Singh, K. Biosynthesis of silver nanocrystals, their kinetic profile from nucleation to growth and optical sensing of mercuric ions. J. Clean. Prod. 2019, 228, 294-302. [CrossRef]

17. Melchert, W.R.; Reis, B.F.; Rocha, F.R.P. Green chemistry and the evolution of flow analysis. A review. Anal. Chim. Acta 2012, 714, 8-19. [CrossRef] [PubMed]

18. Malik, P.; Shankar, R.; Malik, V.; Sharma, N.; Mukherjee, T.K. Green Chemistry Based Benign Routes for Nanoparticle Synthesis. J. Nanopart. 2014, 2014, 1-14. [CrossRef]

19. Sofi, H.S.; Ashraf, R.; Khan, A.H.; Beigh, M.A.; Majeed, S.; Sheikh, F.A. Reconstructing nanofibers from natural polymers using surface functionalization approaches for applications in tissue engineering, drug delivery and biosensing devices. Mater. Sci. Eng. C 2019, 94, 1102-1124. [CrossRef] [PubMed]

20. Sun, Y.; Cheng, S.; Lu, W.; Wang, Y.; Zhang, P.; Yao, Q. Electrospun fibers and their application in drug controlled release, biological dressings, tissue repair, and enzyme immobilization. RSC Adv. 2019, 9, 25712-25729. [CrossRef]

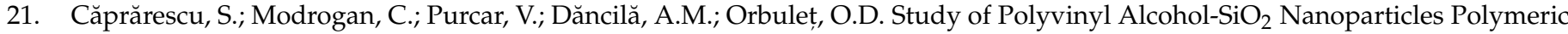
Membrane in Wastewater Treatment Containing Zinc Ions. Polymers 2021, 13, 1875. [CrossRef]

22. Sinha, S.; Pan, I.; Chanda, P.; Sen, S.K. Nanoparticles fabrication using ambient biological resources. J. Appl. Biosci. 2009, 19, 1113-1130.

23. Thakkar, K.N.; Mhatre, S.S.; Parikh, R.Y. Biological synthesis of metallic nanoparticles. Nanomed. Nanotech. Biol. Med. 2010, 6 , 257-262. [CrossRef] [PubMed]

24. Gowramma, B.; Keerthi, U.; Rafi, M.; Muralidhara Rao, D. Biogenic silver nanoparticles production and characterization from native stain of Corynebacterium species and its antimicrobial activity. 3 Biotech 2015, 5, 195-201. [CrossRef] [PubMed]

25. Makarov, V.V.; Love, A.J.; Sinitsyna, O.V.; Makarova, S.S.; Yaminsky, I.V.; Taliansky, M.E.; Kalinina, N.O. “Green” nanotechnologies: Synthesis of metal nanoparticles using plants. Acta Nat. 2014, 6, 35-44. [CrossRef]

26. Mukherjee, P.; Ahmad, A.; Mandal, D.; Senapati, S.; Sainkar, S.R.; Khan, M.I.; Parishcha, R.; Ajaykumar, P.V.; Alam, M.; Kumar, R.; et al. Fungus-Mediated Synthesis of Silver Nanoparticles and Their Immobilization in the Mycelial Matrix: A Novel Biological Approach to Nanoparticle Synthesis. Nano Lett. 2001, 1, 515-519. [CrossRef]

27. Wang, L.; Yao, J.; Zhang, X.; Zhang, Y.; Xu, C.; Lee, R.; Yu, G.; Yu, B.; Teng, L. Delivery of paclitaxel using nanoparticles composed of poly (ethylene oxide)-b-poly (butylene oxide) (PEO-PBO). Colloids Surf. B Biointerfaces 2018, 161, 464-470. [CrossRef]

28. Niculescu, A.G.; Grumezescu, A.M. Polymer-Based Nanosystems-A Versatile Delivery Approach. Materials $2021,14,6812$. [CrossRef]

29. Ahirwar, D.; Bano, M.; Khan, I.; Gound, S.S.; Ud Din Sheik, M.; Mondal, R.; Khan, F. Facile synthesis of macroporous Ag and CuO monoliths as an efficient nonenzymatic electrochemical sensor and antimicrobial agent. J. Solid State Chem. 2019, 273, 233-242. [CrossRef]

30. Zare, M.; Namratha, K.; Alghamdi, S.; Mohammad, Y.H.E.; Hezam, A.; Zare, M.; Drmosh, Q.A.; Byrappa, K.; Nanjegowda, B.; Chandrashekar, S.R.; et al. Novel green biomimetic approach for synthesis of ZnO-Ag nanocomposite; antimicrobial activity against food-borne pathogen, biocompatibility and solar. Sci. Rep. 2019, 9, 8303. [CrossRef]

31. Nadagouda, M.N.; Varma, R.S. Green synthesis of silver and palladium nanoparticles at room temperature using coffee and tea extract. Green Chem. 2008, 10, 859-886. [CrossRef]

32. Elavazhagan, T.; Arunachalam, K.D. Memecylon edule leaf extract mediated green synthesis of silver and gold nanoparticles. Int. J. Nanomed. 2011, 6, 1265-1278. [CrossRef]

33. Lee, Y.W.; Kim, M.; Kim, Z.H.; Han, S.W. One-step synthesis of Au@Pd core-shell nanooctahedron. J. Am. Chem. Soc. 2009, 131, 17036-17037. [CrossRef]

34. Zhang, G.; Liu, Z.; Xiao, Z.; Huang, J.; Li, Q.; Wang, Y.; Sun, D. Ni 2 P-graphite nanoplatelets supported Au-Pd core-shell nanoparticles with superior electrochemical properties. J. Phys. Chem. C 2015, 119, 10469-10477. [CrossRef]

35. Shankar, S.S.; Ahmad, A.; Sastry, M. Geranium Leaf Assisted Biosynthesis of Silver Nanoparticles. Biotechnol. Prog. 2003, 19, 1627-1631. [CrossRef]

36. Ankamwar, B.; Chaudhary, M.; Sastry, M. Gold Nanotriangles Biologically Synthesized using Tamarind Leaf Extract and Potential Application in Vapor Sensing. Synth. React. Inorg. Met. Nano-Metal Chem. 2005, 35, 19-26. [CrossRef] 
37. Gardea-Torresdey, J.L.; Gomez, E.; Peralta-Videa, J.R.; Parsons, J.G.; Troiani, H.; Jose-Yacaman, M. Alfalfa sprouts: A natural source for the synthesis of silver nanoparticles. Langmuir 2003, 19, 1357-1361. [CrossRef]

38. Xin Lee, K.; Shameli, K.; Miyake, M.; Kuwano, N.; Bt Ahmad Khairudin, N.B.; Bt Mohamad, S.E.; Yew, Y.P. Green Synthesis of Gold Nanoparticles Using Aqueous Extract of Garcinia mangostana Fruit Peels. J. Nanomater. 2016, 2016, 7. [CrossRef]

39. Davids, J.S.; Ackah, M.; Okoampah, E.; Fometu, S.S.; Guohua, W.; Jianping, Z. Biocontrol of Bacteria Associated with Pine Wilt Nematode, Bursaphelenchus xylophilus by using Plant mediated Gold Nanoparticles. Int. J. Agric. Biol. 2021, 26, 517-526.

40. Jiang, H.; Manolache, S.; Wong, A.C.L.; Denes, F.S. Plasma-enhanced deposition of silver nanoparticles onto polymer and metal surfaces for the generation of antimicrobial characteristics. J. Appl. Polym. Sci. 2004, 93, 1411-1422. [CrossRef]

41. Thirunavoukkarasu, M.; Balaji, U.; Behera, S.; Panda, P.K.; Mishra, B.K. Biosynthesis of silver nanoparticle from leaf extract of Desmodium gangeticum (L.) DC. and its biomedical potential. Spectrochim. Acta Part A Mol. Biomol. Spectrosc. 2013, 116, $424-427$. [CrossRef] [PubMed]

42. Parlinska-Wojtan, M.; Kus-Liskiewicz, M.; Depciuch, J.; Sadik, O. Green synthesis and antibacterial effects of aqueous colloidal solutions of silver nanoparticles using camomile terpenoids as a combined reducing and capping agent. Bioprocess Biosyst. Eng. 2016, 39, 1213-1223. [CrossRef] [PubMed]

43. Rodríguez-León, E.; Iñiguez-Palomares, R.; Navarro, R.E.; Herrera-Urbina, R.; Tánori, J.; Iñiguez-Palomares, C.; Maldonado, A. Synthesis of silver nanoparticles using reducing agents obtained from natural sources (Rumex hymenosepalus extracts). Nanoscale Res. Lett. 2013, 8, 1-9. [CrossRef] [PubMed]

44. Gopinath, V.; MubarakAli, D.; Priyadarshini, S.; Priyadharsshini, N.M.; Thajuddin, N.; Velusamy, P. Biosynthesis of silver nanoparticles from Tribulus terrestris and its antimicrobial activity: A novel biological approach. Colloids Surf. B Biointerfaces 2012, 96, 69-74. [CrossRef]

45. Sharifi-Rad, M.; Pohl, P.; Epifano, F.; Álvarez-Suarez, J.M. Green Synthesis of Silver Nanoparticles Using Astragalus tribuloides Delile. Root Extract: Characterization, Antioxidant, Antibacterial, and Anti-Inflammatory Activities. Nanomaterials 2020, 10, 2383. [CrossRef]

46. Jha, A.K.; Prasad, K. Green Synthesis of Silver Nanoparticles Using Cycas Leaf. Int. J. Green Nanotechnol. Phys. Chem. 2010, 1, 110-117. [CrossRef]

47. Sathishkumar, M.; Sneha, K.; Yun, Y.S. Immobilization of silver nanoparticles synthesized using Curcuma longa tuber powder and extract on cotton cloth for bactericidal activity. Bioresour. Technol. 2010, 101, 7958-7965. [CrossRef]

48. Kumar, V.; Yadav, S.K. Synthesis of stable, polyshaped silver, and gold nanoparticles using leaf extract of Lonicera japonica L. Int. J. Green Nanotechnol. Biomed. 2011, 3, 281-291. [CrossRef]

49. Banerjee, J.; Narendhirakannan, R.T. Biosynthesis of silver nanoparticles from Syzygium cumini (L.) seed extract and evaluation of their in vitro antioxidant activities. Dig. J. Nanomater. Biostruct. 2011, 6, 961-968.

50. Patil, C.D.; Patil, S.V.; Borase, H.P.; Salunke, B.K.; Salunkhe, R.B. Larvicidal activity of silver nanoparticles synthesized using Plumeria rubra plant latex against Aedes aegypti and Anopheles stephensi. Parasitol. Res. 2012, 110, 1815-1822. [CrossRef]

51. Ponarulselvam, S.; Panneerselvam, C.; Murugan, K.; Aarthi, N.; Kalimuthu, K.; Thangamani, S. Synthesis of silver nanoparticles using leaves of Catharanthus roseus Linn. G. Don and their antiplasmodial activities. Asian Pac. J. Trop. Biomed. 2012, 2, 574-580. [CrossRef]

52. Sathishkumar, M.; Sneha, K.; Won, S.W.; Cho, C.W.; Kim, S.; Yun, Y.S. Cinnamon zeylanicum bark extract and powder mediated green synthesis of nano-crystalline silver particles and its bactericidal activity. Colloids Surf. B Biointerfaces 2009, 73, 332-338. [CrossRef]

53. Harshiny, M.; Matheswaran, M.; Arthanareeswaran, G.; Kumaran, S.; Rajasree, S. Enhancement of antibacterial properties of silver nanoparticles-ceftriaxone conjugate through Mukia maderaspatana leaf extract mediated synthesis. Ecotoxicol. Environ. Saf. 2015, 121, 135-141. [CrossRef]

54. Anandalakshmi, K.; Venugobal, J.; Ramasamy, V. Characterization of silver nanoparticles by green synthesis method using Pedalium murex leaf extract and their antibacterial activity. Appl. Nanosci. 2016, 6, 399-408. [CrossRef]

55. Raju, D.; Paneliya, N.; Mehta, U.J. Extracellular synthesis of silver nanoparticles using living peanut seedling. Appl. Nanosci. 2014, 4, 875-879. [CrossRef]

56. Morales-Lozoya, V.; Espinoza-Gómez, H.; Flores-López, L.Z.; Sotelo-Barrera, E.L.; Núñez-Rivera, A.; Cadena-Nava, R.D.; AlonsoNuñez, G.; Rivero, I.A. Study of the effect of the different parts of Morinda citrifolia L. (noni) on the green synthesis of silver nanoparticles and their antibacterial activity. Appl. Surf. Sci. 2021, 537, 147855. [CrossRef]

57. Gudimalla, A.; Jose, J.; Varghese, R.J.; Thomas, S. Green Synthesis of Silver Nanoparticles Using Nymphae odorata Extract Incorporated Films and Antimicrobial Activity. J. Polym. Environ. 2021, 29, 1412-1423. [CrossRef]

58. Nilavukkarasi, M.; Vijayakumar, S.; Prathip Kumar, S. Biological synthesis and characterization of silver nanoparticles with Capparis zeylanica L. leaf extract for potent antimicrobial and anti proliferation efficiency. Mater. Sci. Energy Technol. 2020, 3, 371-376. [CrossRef]

59. Moteriya, P.; Chanda, S. Green Synthesis of Silver Nanoparticles from Caesalpinia pulcherrima Leaf Extract and Evaluation of Their Antimicrobial, Cytotoxic and Genotoxic Potential (3-in-1 System). J. Inorg. Organomet. Polym. Mater. 2020, 30, $3920-3932$. [CrossRef]

60. Dalir, S.J.B.; Djahaniani, H.; Nabati, F.; Hekmati, M. Characterization and the evaluation of antimicrobial activities of silver nanoparticles biosynthesized from Carya illinoinensis leaf extract. Heliyon 2020, 6, e03624. [CrossRef] 
61. Khatoon, A.; Khan, F.; Ahmad, N.; Shaikh, S.; Rizvi, S.M.D.; Shakil, S.; Al-Qahtani, M.H.; Abuzenadah, A.M.; Tabrez, S.; Ahmed, A.B.F.; et al. Silver nanoparticles from leaf extract of Mentha piperita: Eco-friendly synthesis and effect on acetylcholinesterase activity. Life Sci. 2018, 209, 430-434. [CrossRef] [PubMed]

62. Bar, H.; Bhui, D.K.; Sahoo, G.P.; Sarkar, P.; De, S.P.; Misra, A. Green synthesis of silver nanoparticles using latex of Jatropha curcas Colloids Surf. A Physicochem. Eng. Asp. 2009, 339, 134-139. [CrossRef]

63. Krishnaraj, C.; Jagan, E.G.; Rajasekar, S.; Selvakumar, P.; Kalaichelvan, P.T.; Mohan, N. Synthesis of silver nanoparticles using Acalypha indica leaf extracts and its antibacterial activity against water borne pathogens. Colloids Surf. B Biointerfaces 2010, 76, 50-56. [CrossRef]

64. Philip, D. Green synthesis of gold and silver nanoparticles using Hibiscus rosa sinensis. Phys. E Low-Dimens. Syst. Nanostruct. 2010, 42, 1417-1424. [CrossRef]

65. Awwad, A.M.; Salem, N.M.; Abdeen, A.O. Green synthesis of silver nanoparticles using carob leaf extract and its antibacterial activity. Int. J. Ind. Chem. 2013, 4, 29. [CrossRef]

66. Satyavani, K.; Gurudeeban, S.; Ramanathan, T.; Balasubramanian, T. Toxicity study of silver nanoparticles synthesized from Suaeda monoica on Hep-2 cell line. Avicenna J. Med. Biotechnol. 2012, 4, 35-39. [PubMed]

67. Philip, D.; Unni, C. Extracellular biosynthesis of gold and silver nanoparticles using Krishna tulsi (Ocimum sanctum) leaf. Phys. E Low-Dimens. Syst. Nanostruct. 2011, 43, 1318-1322. [CrossRef]

68. Patil, R.S.; Kokate, M.R.; Kolekar, S.S. Bioinspired synthesis of highly stabilized silver nanoparticles using Ocimum tenuiflorum leaf extract and their antibacterial activity. Spectrochim. Acta Part A Mol. Biomol. Spectrosc. 2012, 91, 234-238. [CrossRef] [PubMed]

69. Song, J.Y.; Kim, B.S. Rapid biological synthesis of silver nanoparticles using plant leaf extracts. Bioprocess Biosyst. Eng. 2009, 32, 79-84. [CrossRef]

70. Dubey, S.P.; Lahtinen, M.; Sillanpää, M. Tansy fruit mediated greener synthesis of silver and gold nanoparticles. Process Biochem. 2010, 45, 1065-1071. [CrossRef]

71. Singh, A.; Jain, D.; Upadhyay, M.K.; Khandelwal, N.; Verma, H.N. Green synthesis of silver nanoparticles using Argemone mexicana leaf extract and evaluation of their antimicrobial activities. Dig. J. Nanomater. Biostruct. 2010, 5, 483-489.

72. Nabikhan, A.; Kandasamy, K.; Raj, A.; Alikunhi, N.M. Synthesis of antimicrobial silver nanoparticles by callus and leaf extracts from saltmarsh plant, Sesuvium portulacastrum L. Colloids Surf. B Biointerfaces 2010, 79, 488-493. [CrossRef] [PubMed]

73. Kumar, V.; Yadav, S.C.; Yadav, S.K. Syzygium cumini leaf and seed extract mediated biosynthesis of silver nanoparticles and their characterization. J. Chem. Technol. Biotechnol. 2010, 85, 1301-1309. [CrossRef]

74. Huang, J.; Li, Q.; Sun, D.; Lu, Y.; Su, Y.; Yang, X.; Wang, H.; Wang, Y.; Shao, W.; He, N.; et al. Biosynthesis of silver and gold nanoparticles by novel sundried Cinnamomum camphora leaf. Nanotechnology 2007, 18, 105104. [CrossRef]

75. Sukirtha, R.; Priyanka, K.M.; Antony, J.J.; Kamalakkannan, S.; Thangam, R.; Gunasekaran, P.; Krishnan, M.; Achiraman, S Cytotoxic effect of Green synthesized silver nanoparticles using Melia azedarach against in vitro HeLa cell lines and lymphoma mice model. Process Biochem. 2012, 47, 273-279. [CrossRef]

76. Mittal, A.K.; Kaler, A.; Banerjee, U.C. Free radical scavenging and antioxidant activity of silver nanoparticles synthesized from flower extract of Rhododendron dauricum. Nano Biomed. Eng. 2012, 4, 118-124. [CrossRef]

77. Cruz, D.; Falé, P.L.; Mourato, A.; Vaz, P.D.; Luisa Serralheiro, M.; Lino, A.R.L. Preparation and physicochemical characterization of Ag nanoparticles biosynthesized by Lippia citriodora (Lemon Verbena). Colloids Surf. B Biointerfaces 2010, 81, 67-73. [CrossRef] [PubMed]

78. Satyavani, K.; Gurudeeban, S.; Ramanathan, T.; Balasubramanian, T. Biomedical potential of silver nanoparticles synthesized from calli cells of Citrullus colocynthis (L.) Schrad. J. Nanobiotechnol. 2011, 9, 1-8.

79. Aromal, S.A.; Philip, D. Green synthesis of gold nanoparticles using Trigonella foenum-graecum and its size-dependent catalytic activity. Spectrochim. Acta Part A Mol. Biomol. Spectrosc. 2012, 97, 1-5. [CrossRef]

80. Singh, A.K.; Talat, M.; Singh, D.P.; Srivastava, O.N. Biosynthesis of gold and silver nanoparticles by natural precursor clove and their functionalization with amine group. J. Nanopart. Res. 2010, 12, 1667-1675. [CrossRef]

81. Sharma, R.K.; Gulati, S.; Mehta, S. Preparation of gold nanoparticles using tea: A green chemistry experiment. J. Chem. Educ. 2012, 89, 1316-1318. [CrossRef]

82. Suman, T.Y.; Radhika Rajasree, S.R.; Ramkumar, R.; Rajthilak, C.; Perumal, P. The Green synthesis of gold nanoparticles using an aqueous root extract of Morinda citrifolia L. Spectrochim. Acta Part A Mol. Biomol. Spectrosc. 2014, 118, 11-16. [CrossRef] [PubMed]

83. Das, R.K.; Gogoi, N.; Bora, U. Green synthesis of gold nanoparticles using Nyctanthes arbortristis flower extract. Bioprocess Biosyst. Eng. 2011, 34, 615-619. [CrossRef] [PubMed]

84. Jha, A.K.; Prasad, K. Biosynthesis of gold nanoparticles using bael (Aegle marmelos) leaf: Mythology meets technology. Int. J. Green Nanotechnol. Biomed. 2011, 3, 92-97. [CrossRef]

85. Rodríguez-León, E.; Rodríguez-Vázquez, B.E.; Martínez-Higuera, A.; Rodríguez-Beas, C.; Larios-Rodríguez, E.; Navarro, R.E.; López-Esparza, R.; Iñiguez-Palomares, R.A. Synthesis of Gold Nanoparticles Using Mimosa tenuiflora Extract, Assessments of Cytotoxicity, Cellular Uptake, and Catalysis. Nanoscale Res. Lett. 2019, 14, 334. [CrossRef]

86. Anuradha, J.; Tasneem, A.; Abbasi, S.A. “Green” Synthesis of Gold Nanoparticles with Aqueous Extracts of Neem (Azadirachta indica). Res. J. Biotechnol. 2010, 5, 75-79.

87. Kasthuri, J.; Kathiravan, K.; Rajendiran, N. Phyllanthin-assisted biosynthesis of silver and gold nanoparticles: A novel biological approach. J. Nanopart. Res. 2009, 11, 1075-1085. [CrossRef] 
88. Aromal, S.A.; Philip, D. Benincasa hispida seed mediated green synthesis of gold nanoparticles and its optical nonlinearity. Phys. E Low-Dimens. Syst. Nanostruct. 2012, 44, 1329-1334. [CrossRef]

89. Muniyappan, N.; Pandeeswaran, M.; Amalraj, A. Green synthesis of gold nanoparticles using Curcuma pseudomontana isolated curcumin: Its characterization, antimicrobial, antioxidant and anti-inflammatory activities. Environ. Chem. Ecotoxicol. 2021, 3 , 117-124. [CrossRef]

90. Kumari, P.; Meena, A. Green synthesis of gold nanoparticles from Lawsoniainermis and its catalytic activities following the Langmuir-Hinshelwood mechanism. Colloids Surf. A Physicochem. Eng. Asp. 2020, 606, 125447. [CrossRef]

91. ElMitwalli, O.S.; Barakat, O.A.; Daoud, R.M.; Akhtar, S.; Henari, F.Z. Green synthesis of gold nanoparticles using cinnamon bark extract, characterization, and fluorescence activity in Au/eosin Y assemblies. J. Nanopart. Res. 2020, 22, 1-9. [CrossRef]

92. Chandran, S.P.; Chaudhary, M.; Pasricha, R.; Ahmad, A.; Sastry, M. Synthesis of gold nanotriangles and silver nanoparticles using Aloe vera plant extract. Biotechnol. Prog. 2006, 22, 577-583. [CrossRef] [PubMed]

93. Jha, A.K.; Prasad, K. Biosynthesis of gold nanoparticles using common aromatic plants. Int. J. Green Nanotechnol. Biomed. 2012, 4 , 219-224. [CrossRef]

94. Shukla, D.; Vankar, P.S. Synthesis of plant parts mediated gold nanoparticles. Int. J. Green Nanotechnol. Biomed. 2012, 4, 277-288. [CrossRef]

95. Philip, D.; Unni, C.; Aromal, S.A.; Vidhu, V.K. Murraya Koenigii leaf-assisted rapid green synthesis of silver and gold nanoparticles Spectrochim. Acta Part A Mol. Biomol. Spectrosc. 2011, 78, 899-904. [CrossRef]

96. Noruzi, M.; Zare, D.; Khoshnevisan, K.; Davoodi, D. Rapid green synthesis of gold nanoparticles using Rosa hybrida petal extract at room temperature. Spectrochim. Acta Part A Mol. Biomol. Spectrosc. 2011, 79, 1461-1465. [CrossRef] [PubMed]

97. Kumar, K.M.; Mandal, B.K.; Sinha, M.; Krishnakumar, V. Terminalia chebula mediated green and rapid synthesis of gold nanoparticles. Spectrochim. Acta Part A Mol. Biomol. Spectrosc. 2012, 86, 490-494. [CrossRef]

98. Pandey, S.; Oza, G.; Mewada, A.; Sharon, M. Green Synthesis of Highly Stable Gold Nanoparticles using Momordica charantia as Nano fabricator. Arch. Appl. Sci. Res. 2012, 4, 1135-1141.

99. Annamalai, A.; Babu, S.T.; Jose, N.A.; Sudha, D.; Lyza, C.V. Biosynthesis and characterization of silver and gold nanoparticles using aqueous leaf extraction of Phyllanthus amarus Schum. \& Thonn. World Appl. Sci. J. 2011, 13, 1833-1840.

100. Philip, D. Rapid green synthesis of spherical gold nanoparticles using Mangifera indica leaf. Spectrochim. Acta Part A Mol. Biomol. Spectrosc. 2010, 77, 807-810. [CrossRef]

101. Mishra, A.N.; Bhadauria, S.; Gaur, M.S.; Pasricha, R.; Kushwah, B.S. Synthesis of Gold Nanoparticles by Leaves of Zero-Calorie Sweetener Herb ( Stevia rebaudiana) and Their Nanoscopic Characterization by Spectroscopy and Microscopy. Int. J. Green Nanotechnol. Phys. Chem. 2010, 1, 118-124. [CrossRef]

102. Sneha, K.; Sathishkumar, M.; Lee, S.Y.; Bae, M.A.; Yun, Y.S. Biosynthesis of Au nanoparticles using cumin seed powder extract. J. Nanosci. Nanotechnol. 2011, 11, 1811-1814. [CrossRef]

103. Dubey, S.P.; Lahtinen, M.; Särkkä, H.; Sillanpää, M. Bioprospective of Sorbus aucuparia leaf extract in development of silver and gold nanocolloids. Colloids Surf. B Biointerfaces 2010, 80, 26-33. [CrossRef] [PubMed]

104. Kajbafvala, A.; Ghorbani, H.; Paravar, A.; Samberg, J.P.; Kajbafvala, E.; Sadrnezhaad, S.K. Effects of morphology on photocatalytic performance of Zinc oxide nanostructures synthesized by rapid microwave irradiation methods. Superlattices Microstruct. 2012, 51, 512-522. [CrossRef]

105. Kumar, S.S.; Venkateswarlu, P.; Rao, V.R.; Rao, G.N. Synthesis, characterization and optical properties of zinc oxide nanoparticles. Int. Nano Lett. 2013, 3, 1-6. [CrossRef]

106. Lingaraju, K.; Raja Naika, H.; Manjunath, K.; Basavaraj, R.B.; Nagabhushana, H.; Nagaraju, G.; Suresh, D. Biogenic synthesis of zinc oxide nanoparticles using Ruta graveolens (L.) and their antibacterial and antioxidant activities. Appl. Nanosci. 2016, 6 , 703-710. [CrossRef]

107. Chaudhuri, S.K.; Malodia, L. Biosynthesis of zinc oxide nanoparticles using leaf extract of calotropis gigantea: Characterization and its evaluation on tree seedling growth in nursery stage. Appl. Nanosci. 2017, 7, 501-512. [CrossRef]

108. Ahmad, H.; Venugopal, K.; Rajagopal, K.; De Britto, S.; Nandini, B.; Pushpalatha, H.G.; Konappa, N.; Udayashankar, A.C.; Geetha, N.; Jogaiah, S. Green synthesis and characterization of zinc oxide nanoparticles using eucalyptus globules and their fungicidal ability against pathogenic fungi of apple orchards. Biomolecules 2020, 10, 425. [CrossRef]

109. Gomathi, R.; Suhana, H. Green synthesis, characterization and antimicrobial activity of zinc oxide nanoparticles using Artemisia pallens plant extract. Inorg. Nano-Metal Chem. 2021, 51, 1663-1672. [CrossRef]

110. Bala, N.; Saha, S.; Chakraborty, M.; Maiti, M.; Das, S.; Basu, R.; Nandy, P. Green synthesis of zinc oxide nanoparticles using Hibiscus subdariffa leaf extract: Effect of temperature on synthesis, anti-bacterial activity and anti-diabetic activity. RSC Adv. 2015, 5, 4993-5003. [CrossRef]

111. Ambika, S.; Sundrarajan, M. Antibacterial behaviour of Vitex negundo extract assisted ZnO nanoparticles against pathogenic bacteria. J. Photochem. Photobiol. B Biol. 2015, 146, 52-57. [CrossRef] [PubMed]

112. Anbuvannan, M.; Ramesh, M.; Viruthagiri, G.; Shanmugam, N.; Kannadasan, N. Anisochilus carnosus leaf extract mediated synthesis of zinc oxide nanoparticles for antibacterial and photocatalytic activities. Mater. Sci. Semicond. Process. 2015, 39, 621-628. [CrossRef]

113. Singh, R.P.; Shukla, V.K.; Yadav, R.S.; Sharma, P.K.; Singh, P.K.; Pandey, A.C. Biological approach of zinc oxide nanoparticles formation and its characterization. Adv. Mater. Lett. 2011, 2, 313-317. [CrossRef] 
114. Ramesh, P.; Rajendran, A.; Sundaram, M. Green Synthesis of Zinc Oxide Nanoparticles Using Flower Extract Cassia Auriculata. J. Nanosci. Nanotechnol. 2014, 2, 41-45.

115. Jayachandran, A.; Aswathy, T.R.; Nair, A.S. Green synthesis and characterization of zinc oxide nanoparticles using Cayratia pedata leaf extract. Biochem. Biophys. Rep. 2021, 26, 100995. [CrossRef]

116. Ahmad, W.; Kalra, D. Green synthesis, characterization and anti-microbial activities of ZnO nanoparticles using Euphorbia hirta leaf extract. J. King Saud Univ.-Sci. 2020, 32, 2358-2364. [CrossRef]

117. Sharmila, G.; Thirumarimurugan, M.; Muthukumaran, C. Green synthesis of ZnO nanoparticles using Tecoma castanifolia leaf extract: Characterization and evaluation of its antioxidant, bactericidal and anticancer activities. Microchem. J. 2019, 145, 578-587. [CrossRef]

118. Raj, L.F.A.; Jayalakshmy, E. Biosynthesis and characterization of zinc oxide nanoparticles using root extract of Zingiber officinale. Orient. J. Chem. 2015, 31, 51-56. [CrossRef]

119. Noorjahan, C.M.; Shahina, S.K.J.; Deepika, T.; Rafiq, S. Green Synthesis and Characterization of Zinc Oxide Nanoparticles from Neem (Azadirachta indicia). Int. J. Sci. Eng. Technol. Res. 2015, 4, 5751-5753.

120. Savithramma, N.; Bhumi, G. Biological Synthesis of Zinc oxide Nanoparticles from C atharanthus roseus (1.) G. Don. Leaf extract and validation for antibacterial activity. Int. J. Drug Dev. Res. 2014, 6, 208-214.

121. Ramesh, M.; Anbuvannan, M.; Viruthagiri, G. Green synthesis of ZnO nanoparticles using Solanum nigrum leaf extract and their antibacterial activity. Spectrochim. Acta Part A Mol. Biomol. Spectrosc. 2015, 136, 864-870. [CrossRef] [PubMed]

122. Awwad, A.M.; Albiss, B.; Ahmad, A.L. Green synthesis, characterization and optical properties of zinc oxide nanosheets using Olea europea leaf extract. Adv. Mater. Lett. 2014, 5, 520-524. [CrossRef]

123. Oudhia, A.; Kulkarni, P.; Sharma, S. Green Synthesisof ZnO nanotubes for Bioapplications. J. Adv. Eng. Res. Stud. 2015, 280-281.

124. Jamdagni, P.; Khatri, P.; Rana, J.S. Green synthesis of zinc oxide nanoparticles using flower extract of Nyctanthes arbor-tristis and their antifungal activity. J. King Saud Univ.-Sci. 2018, 30, 168-175. [CrossRef]

125. Devi, R.; Gayathri, R. Green Synthesis of Zinc Oxide Nanoparticles by using Hibiscus rosa-sinensis. Int. J. Curr. Eng. Technol. 2014, 44, 2444-2446.

126. Varghese, E.; George, M. Green synthesis of zinc oxide nanoparticles. Int. J. Adv. Res. Sci. Eng. 2015, 4, 307-314.

127. Raut, S.; Thorat, P.V.; Thakre, R. Green Synthesis of Zinc Oxide (ZnO) Nanoparticles Using Ocimum Tenuiflorum Leaves. Int. J. Sci. Res. 2013, 4, 2319-7064.

128. Azizi, S.; Ahmad, M.B.; Namvar, F.; Mohamad, R. Green biosynthesis and characterization of zinc oxide nanoparticles using brown marine macroalga Sargassum muticum aqueous extract. Mater. Lett. 2014, 116, 275-277. [CrossRef]

129. Kumar, M.A.P.; Suresh, D.; Nagabhushana, H.; Sharma, S.C. Beta vulgaris aided green synthesis of ZnO nanoparticles and their luminescence, photocatalytic and antioxidant properties. Eur. Phys. J. Plus 2015, 130, 1-7.

130. Fatimah, I.; Yudha, S.P.; Mutiara, N.A.L. Green synthesis of ZnO nanoparticles via complex formation by using Curcuma longa extract Proceedings of 6th Nanoscience and Nanotechnology Symposium (NNS2015), Sukarta, Indonesia, 4-5 November 2015; Purwano, A., Nur, A., Rahmawati, F., Dyartanti, E.R., Jumari, A., Eds.; AIP Publishing LLC: Melville, NY, USA, 2015.

131. Yuvakkumar, R.; Suresh, J.; Hong, S.I. Green synthesis of zinc oxide nanoparticles. Adv. Mater. Res. 2014, 952, 137-140. [CrossRef]

132. Suresh, D.; Shobharani, R.M.; Nethravathi, P.C.; Pavan Kumar, M.A.; Nagabhushana, H.; Sharma, S.C. Artocarpus gomezianus aided green synthesis of $\mathrm{ZnO}$ nanoparticles: Luminescence, photocatalytic and antioxidant properties. Spectrochim. Acta Part A Mol. Biomol. Spectrosc. 2015, 141, 128-134. [CrossRef] [PubMed]

133. Sindhura, K.S.; Tnvkv, P.; Selvam, P.P.; Hussain, O.M. Green Synthesis of Zinc Nanoparticles from Senna Auriculata and Influence on Peanut Pot-Culture. Int. J. Res. Agric. Sci. 2015, 2, 61-69.

134. Raj, A.; Lawrence, R.S.; Jalees, M.; Lawrence, K. Anti-Bacterial Activity of Zinc Oxide Nanoparticles Prepared from Brassica Oleraceae Leaves Extract. Int. J. Adv. Res. 2015, 3, 322-328.

135. Gnanasangeetha, D.; Thambavani, D. Biological and Physical Sciences Biogenic Production of Zinc Oxide Nanoparticles Using Acalypha Indica. J. Chem. Biol. Phys. Sci. 2014, 4, 238-246.

136. Vijayakumar, S.; Vinoj, G.; Malaikozhundan, B.; Shanthi, S.; Vaseeharan, B. Plectranthus amboinicus leaf extract mediated synthesis of zinc oxide nanoparticles and its control of methicillin resistant Staphylococcus aureus biofilm and blood sucking mosquito larvae. Spectrochim. Acta Part A Mol. Biomol. Spectrosc. 2015, 137, 886-891. [CrossRef]

137. Nagajyothi, P.C.; Sreekanth, T.V.M.; Tettey, C.O.; Jun, Y.I.; Mook, S.H. Characterization, antibacterial, antioxidant, and cytotoxic activities of $\mathrm{ZnO}$ nanoparticles using Coptidis Rhizoma. Bioorganic Med. Chem. Lett. 2014, 24, 4298-4303. [CrossRef] [PubMed]

138. Janaki, A.C.; Sailatha, E.; Gunasekaran, S. Synthesis, characteristics and antimicrobial activity of ZnO nanoparticles. Spectrochim. Acta Part A Mol. Biomol. Spectrosc. 2015, 144, 17-22. [CrossRef]

139. Lai, Y.; Wang, L.; Liu, D.; Chen, Z.; Lin, C. TiO2-Based Nanomaterials: Design, Synthesis, and Applications. J. Nanomater. 2015, 2015, 1-3. [CrossRef]

140. Altikatoglu Yapaoz, M.; Attar, A. Salvia officinalis-derived rutile $\mathrm{TiO}_{2} \mathrm{NPs}$ : Production, characterization, antibacterial evaluation and its effect on decolorization. Mater. Res. Express 2019, 6, 55039. [CrossRef]

141. Mahmoud, W.M.M.; Rastogi, T.; Kümmerer, K. Application of titanium dioxide nanoparticles as a photocatalyst for the removal of micropollutants such as pharmaceuticals from water. Curr. Opin. Green Sustain. Chem. 2017, 6, 1-10. [CrossRef]

142. Abel, S.; Jule, L.T.; Belay, F.; Shanmugam, R.; Dwarampudi, L.P.; Nagaprasad, N.; Krishnaraj, R. Application of Titanium Dioxide Nanoparticles Synthesized by Sol-Gel Methods in Wastewater Treatment. J. Nanomater. 2021, 2021, 3039761. [CrossRef] 
143. Rajakumar, G.; Rahuman, A.A.; Priyamvada, B.; Khanna, V.G.; Kumar, D.K.; Sujin, P.J. Eclipta prostrata leaf aqueous extract mediated synthesis of titanium dioxide nanoparticles. Mater. Lett. 2012,68, 115-117. [CrossRef]

144. Subhashini, D.; Nachiyar, C.V. Albizia saman: A Green Route for the Reduction of Bulk TiÖ2. Int. J. Chem Tech. Res. 2014, 6, 5137-5141.

145. Jalill, R.D.A.; Nuaman, R.S.; Abd, A.N. Biological synthesis of Titanium Dioxide nanoparticles by Curcuma longa plant extract and study its biological properties. World Sci. News 2016, 49, 204-222.

146. Dobrucka, R. Synthesis of titanium dioxide nanoparticles using Echinacea purpurea herba. Iran. J. Pharm. Res. 2017, 16, 753-759.

147. Aswini, R.; Murugesan, S.; Kannan, K. Bio-engineered $\mathrm{TiO}_{2}$ nanoparticles using Ledebouria revoluta extract: Larvicidal, histopathological, antibacterial and anticancer activity. Int. J. Environ. Anal. Chem. 2021, 101, 2926-2936. [CrossRef]

148. Narayanan, M.; Devi, P.G.; Natarajan, D.; Kandasamy, S.; Devarayan, K.; Alsehli, M.; Elfasakhany, A.; Pugazhendhi, A. Green synthesis and characterization of titanium dioxide nanoparticles using leaf extract of Pouteria campechiana and larvicidal and pupicidal activity on Aedes aegypti. Environ. Res. 2021, 200, 111333. [CrossRef]

149. Sethy, N.K.; Arif, Z.; Mishra, P.K.; Kumar, P. Green synthesis of $\mathrm{TiO}_{2}$ nanoparticles from Syzygium cumini extract for photocatalytic removal of lead $(\mathrm{Pb})$ in explosive industrial wastewater. Green Process. Synth. 2020, 9, 171-181. [CrossRef]

150. Ahmad, W.; Jaiswal, K.K.; Soni, S. Green synthesis of titanium dioxide $\left(\mathrm{TiO}_{2}\right)$ nanoparticles by using Mentha arvensis leaves extract and its antimicrobial properties. Inorg. Nano-Metal Chem. 2020, 50, 1032-1038. [CrossRef]

151. Thakur, B.K.; Kumar, A.; Kumar, D. Green synthesis of titanium dioxide nanoparticles using Azadirachta indica leaf extract and evaluation of their antibacterial activity. S. Afr. J. Bot. 2019, 124, 223-227. [CrossRef]

152. Santhoshkumar, T.; Rahuman, A.A.; Jayaseelan, C.; Rajakumar, G.; Marimuthu, S.; Kirthi, A.V.; Velayutham, K.; Thomas, J.; Venkatesan, J.; Kim, S.K. Green synthesis of titanium dioxide nanoparticles using Psidium guajava extract and its antibacterial and antioxidant properties. Asian Pac. J. Trop. Med. 2014, 7, 968-976. [CrossRef]

153. Sundrarajan, M.; Gowri, S. Green synthesis of titanium dioxide nanoparticles by nyctanthes arbor-tristis leaves extract. Chalcogenide Lett. 2011, 8, 447-451.

154. Marimuthu, S.; Rahuman, A.A.; Jayaseelan, C.; Kirthi, A.V.; Santhoshkumar, T.; Velayutham, K.; Bagavan, A.; Kamaraj, C.; Elango, G.; Iyappan, M.; et al. Acaricidal activity of synthesized titanium dioxide nanoparticles using Calotropis gigantea against Rhipicephalus microplus and Haemaphysalis bispinosa. Asian Pac. J. Trop. Med. 2013, 6, 682-688. [CrossRef]

155. Rajakumar, G.; Rahuman, A.A.; Jayaseelan, C.; Santhoshkumar, T.; Marimuthu, S.; Kamaraj, C.; Bagavan, A.; Zahir, A.A.; Kirthi, A.V.; Elango, G.; et al. Solanum trilobatum extract-mediated synthesis of titanium dioxide nanoparticles to control Pediculus humanus capitis, Hyalomma anatolicum anatolicum and Anopheles subpictus. Parasitol. Res. 2014, 113, 469-479. [CrossRef]

156. Sankar, R.; Rizwana, K.; Shivashangari, K.S.; Ravikumar, V. Ultra-rapid photocatalytic activity of Azadirachta indica engineered colloidal titanium dioxide nanoparticles. Appl. Nanosci. 2015, 5, 731-736. [CrossRef]

157. Velayutham, K.; Rahuman, A.A.; Rajakumar, G.; Santhoshkumar, T.; Marimuthu, S.; Jayaseelan, C.; Bagavan, A.; Kirthi, A.V.; Kamaraj, C.; Zahir, A.A.; et al. Evaluation of Catharanthus roseus leaf extract-mediated biosynthesis of titanium dioxide nanoparticles against Hippobosca maculata and Bovicola ovis. Parasitol. Res. 2012, 111, 2329-2337. [CrossRef]

158. Nwanya, A.C.; Ugwuoke, P.E.; Ejikeme, P.M.; Oparaku, O.U.; Ezema, F.I. Jathropha curcas and citrus aurantium leaves dye extract for use in dye sensitized solar cell with $\mathrm{TiO}_{2}$ films. Int. J. Electrochem. Sci. 2012, 7, 11219-11235.

159. Hudlikar, M.; Joglekar, S.; Dhaygude, M.; Kodam, K. Green synthesis of $\mathrm{TiO}_{2}$ nanoparticles by using aqueous extract of Jatropha curcas L. latex. Mater. Lett. 2012, 75, 196-199. [CrossRef]

160. Zahir, A.A.; Chauhan, I.S.; Bagavan, A.; Kamaraj, C.; Elango, G.; Shankar, J.; Arjaria, N.; Roopan, S.M.; Rahuman, A.A.; Singh, N. Green synthesis of silver and titanium dioxide nanoparticles using Euphorbia prostrata extract shows shift from apoptosis to G0/G1 arrest followed by necrotic cell death in Leishmania donovani. Antimicrob. Agents Chemother. 2015, 59, 4782-4799. [CrossRef]

161. Rao, K.G.; Ashok, C.; Rao, K.V.; Chakra, C.S.; Rajendar, V. Synthesis of $\mathrm{TiO}_{2}$ nanoparticles from orange fruit waste. Int. J. Multidiscip. Adv. Res. Trends 2015, 2, 82-90.

162. Valli, D.G.; Geetha, S. A green method for the synthesis of titanium dioxide nanoparticles using Cassia auriculata leaves extract. Eur. J. Biomed. Pharm. Sci. 2015, 2, 490-497.

163. Salam, H.A.; Sivaraj, R. Ocimum basilicum L. var. purpurascens Benth.-Lamiaceae Mediated Green Synthesis and Characterization of Titanium Dioxide Nanoparticles. Adv. Biores. 2014, 5, 10-16.

164. Valli, G.; Jayalakshmi, A. Erythrina variegate leaves extract assisted synthesis of titanium dioxide nanoparticles in an eco-friendly approach. Eur. J. Biomed. Pharm. Sci. 2015, 2, 1228-1236.

165. Siddiqi, K.S.; Husen, A. Green Synthesis, Characterization and Uses of Palladium/Platinum Nanoparticles. Nanoscale Res. Lett. 2016, 11, 482. [CrossRef] [PubMed]

166. Gurunathan, S.; Kim, E.S.; Han, J.W.; Park, J.H.; Kim, J.-H.H.; Grumezescu, A.M. Green chemistry approach for synthesis of effective anticancer palladium nanoparticles. Molecules 2015, 20, 22476-22498. [CrossRef]

167. Nasrollahzadeh, M.; Sajadi, S.M.; Maham, M. Green synthesis of palladium nanoparticles using Hippophae rhamnoides Linn leaf extract and their catalytic activity for the Suzuki-Miyaura coupling in water. J. Mol. Catal. A Chem. 2015, 396, 297-303. [CrossRef] 
168. Khan, M.; Albalawi, G.H.; Shaik, M.R.; Khan, M.; Adil, S.F.; Kuniyil, M.; Alkhathlan, H.Z.; Al-Warthan, A.; Siddiqui, M.R.H. Miswak mediated green synthesized palladium nanoparticles as effective catalysts for the Suzuki coupling reactions in aqueous media. J. Saudi Chem. Soc. 2017, 21, 450-457. [CrossRef]

169. Sathishkumar, M.; Sneha, K.; Kwak, I.S.; Mao, J.; Tripathy, S.J.; Yun, Y.S. Phyto-crystallization of palladium through reduction process using Cinnamom zeylanicum bark extract. J. Hazard. Mater. 2009, 171, 400-404. [CrossRef] [PubMed]

170. Khan, M.M.; Khan, M.M.; Kuniyil, M.; Adil, S.F.; Al-Warthan, A.; Alkhathlan, H.Z.; Tremel, W.; Tahir, M.N.; Siddiqui, M.R.H. Biogenic synthesis of palladium nanoparticles using Pulicaria glutinosa extract and their catalytic activity towards the Suzuki coupling reaction. Dalt. Trans. 2014, 43, 9026-9031. [CrossRef]

171. Kumar Petla, R.; Vivekanandhan, S.; Misra, M.; Kumar Mohanty, A.; Satyanarayana, N. Soybean (Glycine Max) Leaf Extract Based Green Synthesis of Palladium Nanoparticles. J. Biomater. Nanobiotechnol. 2012, 3, 14-19. [CrossRef]

172. Jia, L.; Zhang, Q.; Li, Q.; Song, H. The biosynthesis of palladium nanoparticles by antioxidants in Gardenia jasminoides Ellis: Long lifetime nanocatalysts for p-nitrotoluene hydrogenation. Nanotechnology 2009, 20, 385601-385611. [CrossRef]

173. Fahmy, S.A.; Fawzy, I.M.; Saleh, B.M.; Issa, M.Y.; Bakowsky, U.; Azzazy, H.M.E.S. Green synthesis of platinum and palladium nanoparticles using Peganum harmala L. Seed alkaloids: Biological and computational studies. Nanomaterials 2021, 11, 965. [CrossRef] [PubMed]

174. Bathula, C.; Subalakshmi, K.; Kumar, A.; Yadav, H.; Ramesh, S.; Shinde, S.; Shrestha, N.K.; Mallikarjuna, K.; Kim, H. Ultrasonically driven green synthesis of palladium nanoparticles by Coleus amboinicus for catalytic reduction and Suzuki-Miyaura reaction. Colloids Surf. B Biointerfaces 2020, 192, 111026. [CrossRef]

175. Kora, A.J.; Rastogi, L. Green synthesis of palladium nanoparticles using gum ghatti (Anogeissus latifolia) and its application as an antioxidant and catalyst. Arab. J. Chem. 2018, 11, 1097-1106. [CrossRef]

176. Sharmila, G.; Farzana Fathima, M.; Haries, S.; Geetha, S.; Manoj Kumar, N.; Muthukumaran, C. Green synthesis, characterization and antibacterial efficacy of palladium nanoparticles synthesized using Filicium decipiens leaf extract. J. Mol. Struct. 2017, 1138, 35-40. [CrossRef]

177. Yang, X.; Li, Q.; Wang, H.; Huang, J.; Lin, L.; Wang, W.; Sun, D.; Su, Y.; Opiyo, J.B.; Hong, L.; et al. Green synthesis of palladium nanoparticles using broth of Cinnamomum camphora leaf. J. Nanopart. Res. 2010, 12, 1589-1598. [CrossRef]

178. Bankar, A.; Joshi, B.; Kumar, A.R.; Zinjarde, S. Banana peel extract mediated novel route for the synthesis of palladium nanoparticles. Mater. Lett. 2010, 64, 1951-1953. [CrossRef]

179. Kalaiselvi, A.; Roopan, S.M.; Madhumitha, G.; Ramalingam, C.; Elango, G. Synthesis and characterization of palladium nanoparticles using Catharanthus roseus leaf extract and its application in the photo-catalytic degradation. Spectrochim. Acta Part A Mol. Biomol. Spectrosc. 2015, 135, 116-119. [CrossRef] [PubMed]

180. Sathishkumar, M.; Sneha, K.; Yun, Y. Palladium Nanocrystal Synthesis Using Curcuma longa Tuber Extract. Int. J. Mater. Sci. 2009, 4, 11-17.

181. Muthu, K.; Priya, S. Green synthesis, characterization and catalytic activity of silver nanoparticles using Cassia auriculata flower extract separated fraction. Spectrochim. Acta Part A Mol. Biomol. Spectrosc. 2017, 179, 66-72. [CrossRef]

182. Ramesh, A.V.; Devi, D.R.; Battu, G.R.; Basavaiah, K. A Facile plant mediated synthesis of silver nanoparticles using an aqueous leaf extract of Ficus hispida Linn. f. for catalytic, antioxidant and antibacterial applications. S. Afr. J. Chem. Eng. 2018, 26, 25-34. [CrossRef]

183. Armendariz, V.; Herrera, I.; Peralta-Videa, J.R.; Jose-Yacaman, M.; Troiani, H.; Santiago, P.; Gardea-Torresdey, J.L. Size controlled gold nanoparticle formation by Avena sativa biomass: Use of plants in nanobiotechnology. J. Nanopart. Res. 2004, 6, 377-382. [CrossRef]

184. Zulfiqar, H.; Zafar, A.; Rasheed, M.N.; Ali, Z.; Mehmood, K.; Mazher, A.; Hasan, M.; Mahmood, N. Synthesis of silver nanoparticles using Fagonia cretica and their antimicrobial activities. Nanoscale Adv. 2019, 1, 1707-1713. [CrossRef]

185. Pasca, R.D.; Mocanu, A.; Cobzac, S.C.; Petean, I.; Horovitz, O.; Tomoaia-Cotisel, M. Biogenic Syntheses of Gold Nanoparticles Using Plant Extracts. Part. Sci. Technol. 2014, 32, 131-137. [CrossRef]

186. Dhamecha, D.; Jalalpure, S.; Jadhav, K. Nepenthes khasiana mediated synthesis of stabilized gold nanoparticles: Characterization and biocompatibility studies. J. Photochem. Photobiol. B Biol. 2016, 154, 108-117. [CrossRef]

187. Lee, K.X.; Shameli, K.; Mohamad, S.E.; Yew, Y.P.; Isa, E.D.M.; Yap, H.Y.; Lim, W.L.; Teow, S.Y. Bio-Mediated Synthesis and Characterisation of Silver Nanocarrier, and Its Potent Anticancer Action. Nanomaterials 2019, 9, 1423. [CrossRef]

188. Silva-De-Hoyos, L.E.; Sánchez-Mendieta, V.; Rico-Moctezuma, A.; Vilchis-Nestor, A.R.; Camacho-López, M.A.; Avalos-Borja, M. Silver nanoparticles biosynthesized using Opuntia ficus aqueous extract. Superf. Vacio 2012, 25, 31-35.

189. Fayaz, A.M.; Balaji, K.; Kalaichelvan, P.T.; Venkatesan, R. Fungal based synthesis of silver nanoparticles-An effect of temperature on the size of particles. Colloids Surf. B Biointerfaces 2009, 74, 123-126. [CrossRef]

190. Khalil, M.M.H.; Ismail, E.H.; El-Baghdady, K.Z.; Mohamed, D. Green synthesis of silver nanoparticles using olive leaf extract and its antibacterial activity. Arab. J. Chem. 2014, 7, 1131-1139. [CrossRef]

191. Song, J.Y.; Jang, H.K.; Kim, B.S. Biological synthesis of gold nanoparticles using Magnolia kobus and Diopyros kaki leaf extracts. Process Biochem. 2009, 44, 1133-1138. [CrossRef]

192. Philip, D. Mangifera Indica leaf-assisted biosynthesis of well-dispersed silver nanoparticles. Spectrochim. Acta Part A Mol. Biomol. Spectrosc. 2011, 78, 327-331. [CrossRef] [PubMed] 
193. Ghoreishi, S.M.; Behpour, M.; Khayatkashani, M. Green synthesis of silver and gold nanoparticles using Rosa damascena and its primary application in electrochemistry. Phys. E Low-Dimens. Syst. Nanostruct. 2011, 44, 97-104. [CrossRef]

194. Dwivedi, A.D.; Gopal, K. Biosynthesis of silver and gold nanoparticles using Chenopodium album leaf extract. Colloids Surf. A Physicochem. Eng. Asp. 2010, 369, 27-33. [CrossRef]

195. Masum, M.I.; Siddiqa, M.M.; Ali, K.A.; Zhang, Y.; Abdallah, Y.; Ibrahim, E.; Qiu, W.; Yan, C.; Li, B. Biogenic synthesis of silver nanoparticles using phyllanthus emblicafruit extract and its inhibitory action against the pathogen acidovorax oryzaestrain RS-2 of rice bacterial brown stripe. Front. Microbiol. 2019, 10, 820. [CrossRef] [PubMed]

196. Elahi, N.; Kamali, M.; Baghersad, M. Recent biomedical applications of gold nanoparticles: A review. Talanta 2018, 184, 537-556. [CrossRef]

197. Viet Long, N.; Yang, Y.; Teranishi, T.; Minh Thi Ho Chi, C.; Minh Thi, C.; Cao, Y.; Nogami, M. Biomedical applications of advanced multifunctional magnetic nanoparticles. J. Nanosci. Nanotechnol. 2015, 15, 10091-10107. [CrossRef]

198. Rubilar, O.; Rai, M.; Tortella, G.; Diez, M.C.; Seabra, A.B.; Durán, N. Biogenic nanoparticles: Copper, copper oxides, copper sulphides, complex copper nanostructures and their applications. Biotechnol. Lett. 2013, 35, 1365-1375. [CrossRef]

199. Wang, J.; Liu, R.; Liu, B. Cadmium-containing quantum dots: Current perspectives on their application as nanomedicine and toxicity concerns. Mini Rev. Med. Chem. 2016, 16, 905-916. [CrossRef]

200. Khan, S.T.; Malik, A. Engineered nanomaterials for water decontamination and purification: From lab to products. J. Hazard. Mater. 2019, 363, 295-308. [CrossRef]

201. Wilson, M.P.; Schwarzman, M.R. Toward a new U.S. chemicals policy: Rebuilding the foundation to advance new science, green chemistry, and environmental health. Environ. Health Perspect. 2009, 117, 1202-1209. [CrossRef] [PubMed]

202. Benjamin, S.R.; de Lima, F.; Florean, E.O.P.T.; Guedes, M.I.F. Current trends in nanotechnology for bioremediation. Int. J. Environ. Pollut. 2019, 66, 19-40. [CrossRef]

203. Chen, J.; Zheng, A.; Chen, A.; Gao, Y.; He, C.; Kai, X. A functionalized gold nanoparticles and Rhodamine 6G based fluorescent sensor for high sensitive and selective detection of mercury (II) in environmental water. Anal. Chim. Acta 2007, 599, 134-142. [CrossRef] [PubMed]

204. Wu, W.; Xiao, X.; Zhang, S.; Ren, F.; Jiang, C. Facile method to synthesize magnetic iron oxides/TiO 2 hybrid nanoparticles and their photodegradation application of methylene blue. Nanoscale Res. Lett. 2011, 6, 1-15. [CrossRef] [PubMed]

205. Thomas, P.; Rumjit, N.P.; George, P.J.; Lai, C.W.; Tyagi, P.; Johan, M.R.B.; Saravanakumar, M.P. Remediation of heavy metal Ions using nanomaterials sourced from wastewaters. In Nanotechnology for Food, Agriculture and Environment; Springer Science and Business Media B.V.: Berlin/Heidelberg, Germany, 2020; pp. 255-296.

206. Bashir, A.; Razanamahandry, L.; Nwanya, A.; Kaviyarasu, K.; Saban, W.; Mohamed, H.; Ntwampe, S.; Ezema, F.; Maaza, M. Biosynthesis of $\mathrm{NiO}$ nanoparticles for photodegradation of free cyanide solutions under ultraviolet light. J. Phys. Chem. Solids 2019, 134, 133-140. [CrossRef]

207. Varadavenkatesan, T.; Lyubchik, E.; Pai, S.; Pugazhendhi, A.; Vinayagam, R.; Selvaraj, R. Photocatalytic degradation of Rhodamine B by zinc oxide nanoparticles synthesized using the leaf extract of Cyanometra ramiflora. J. Photochem. Photobiol. B Biol. 2019, 199, 111621. [CrossRef] [PubMed]

208. Rogozea, E.; Petcu, A.; Olteanu, N.; Lazar, C.; Cadar, D.; Mihaly, M. Tandem adsorption-photodegradation activity induced by light on NiO-ZnO p-n couple modified silica nanomaterials. Mater. Sci. Semicond. Process. 2017, 57, 1-11. [CrossRef] 